\title{
Particle formation in the Arctic free troposphere during the ASTAR 2004 campaign: a case study on the influence of vertical motion on the binary homogeneous nucleation of $\mathrm{H}_{2} \mathrm{SO}_{4} / \mathrm{H}_{2} \mathrm{O}$
}

\author{
F. Khosrawi ${ }^{1}$, J. Ström ${ }^{2}$, A. Minikin ${ }^{3}$, and R. Krejci ${ }^{4}$ \\ ${ }^{1}$ MISU, Stockholm University, Stockholm, Sweden \\ ${ }^{2}$ Norwegian Polar Institute, Troms $\varnothing$, Norway \\ ${ }^{3}$ DLR, Oberpfaffenhofen, Germany \\ ${ }^{4}$ ITM, Stockholm University, Stockholm, Sweden
}

Received: 31 August 2009 - Published in Atmos. Chem. Phys. Discuss.: 20 October 2009

Revised: 22 January 2010 - Accepted: 27 January 2010 - Published: 2 February 2010

\begin{abstract}
During the ASTAR (Arctic Study of Tropospheric Aerosol and Radiation) campaign nucleation mode particles (4 to $13 \mathrm{~nm}$ ) were quite frequently observed at altitudes below $4000 \mathrm{~m}$. However, in the upper free troposphere, nucleation mode particles were only observed once, namely during the flight on 24 May $2004(7000 \mathrm{~m})$. To investigate if vertical motion were the reason for this difference that on one particular day nucleation mode particles were observed but not on the other days we employ a microphysical box model. The box model simulations were performed along air parcel trajectories calculated 6-d backwards based on European Center for Medium-Range Weather Forecasts (ECMWF) meteorological analyses using state parameters such as pressure and temperature in combination with additional parameters such as vertical stability. Box model simulations were performed for the 24 May where nucleation mode particles were observed (nucleation event) as well as for the days with measurements before and after (22 and 26 May) which are representative for no nucleation (non-nucleation event). A nucleation burst was simulated along all trajectories, however, in the majority of the simulations the nucleation rate was either too low or too high so that no nucleation mode particles were left at the time when the measurements were performed. Further, the simulation results could be divided into three cases. Thereby, we found that for case 1 the temperature was the only driving mechanism for the formation of new particles while for case 2 and 3 vertical motion have
\end{abstract}

Correspondence to: F. Khosrawi (farah@misu.su.se) influenced the formation of new particles. The reason why nucleation mode particles were observed on 24 May, but not on the other days, can be explained by the conditions under which particle formation occurred. On 24 May the particle formation was caused by a slow updraft, while on the other two days the particle formation was caused by a fast updraft.

\section{Introduction}

Atmospheric aerosols affect the Earth's climate either directly or indirectly. The direct effect is associated with aerosol particles absorbing and scattering the incoming solar radiation while the indirect effect is due to the potential of atmospheric aerosols to serve as cloud condensation nuclei. Clouds will reflect the incoming solar radiation while absorbing and emitting the long-wave radiation. Aerosol formation processes are still not entirely understood. Further, there are still high uncertainties in the current global climate model simulations for predicting the future climate due to our limited understanding of the radiation effect of aerosols and clouds (IPCC, 2007).

The nucleation (gas-to-particle conversion) is a source for new particles in the atmosphere. The classical mechanism for the formation of aerosol particles from condensable gases is the binary homogeneous nucleation of sulfuric acid $\left(\mathrm{H}_{2} \mathrm{SO}_{4}\right)$ and water $\left(\mathrm{H}_{2} \mathrm{O}\right)$. However, new aerosol particles can also be formed by other nucleation mechanisms like e.g. the ternary homogeneous nucleation involving ammonia (e.g., Coffmann and Hegg, 1995; Korhonen et al., 1999; Napari et al., 2002; Yu, F. , 2006; Benson et al., 2009) and the

Published by Copernicus Publications on behalf of the European Geosciences Union. 
ion-mediated or ion-induced nucleation (e.g., Yu and Turco, 2000; Lee et al., 2003; Lovejoy et al., 2004; Curtius et. al., 2006; Laaksonen et al., 2008). Laboratory experiments have suggested that in polluted areas nucleation of new particles may even take place inside clouds through condensation of organic vapors (Kulmala et al., 2006). A good overview over all these different nucleation processes and some further references can be found in Hegg and Baker (2009). New particle formation events have been observed at a number of sites around the world (Kulmala et al., 2004).

The binary homogeneous nucleation of $\mathrm{H}_{2} \mathrm{SO}_{4}$ and $\mathrm{H}_{2} \mathrm{O}$ is mainly dependent on temperature, relative humidity and relative acidity (or partial pressure of $\mathrm{H}_{2} \mathrm{SO}_{4}$ ). Atmospheric measurements and numerical simulations have shown that the binary homogeneous nucleation of $\mathrm{H}_{2} \mathrm{SO}_{4}$ and $\mathrm{H}_{2} \mathrm{O}$ occurs mainly in the upper tropical troposphere due to the low temperatures in that region (Brock et al., 1995). At other altitudes and latitudes regions particle formation by binary homogeneous nucleation is relatively small (Raes et al., 1995). However, new particle formation has been observed by aircraft measurements also in the midlatitude free/upper troposphere and lower stratosphere (de Reus et al., 1998, 1999; Lee et al., 2003; Minikin et al., 2003; Hermann et al., 2003; Young et al., 2007) as well as in the Arctic free troposphere (Brock et al., 1989; Weber et al., 2003). The observations of particle formation above $4 \mathrm{~km}$ can be well explained by the binary homogeneous nucleation while at altitudes below $4 \mathrm{~km}$ other nucleation processes seem to be involved in the particle formation (Weber et al., 1999).

The observed particle formation events in the free troposphere and lower stratosphere were often dynamically induced. Hermann et al. (2003) measured particle number concentrations over three years on a German commercial aircraft in the latitude range from $5^{\circ}$ to $50^{\circ}$ and found that photochemistry and solar radiation (tropics) as well as atmospheric dynamics (midaltitudes, tropics) were the driving forces for aerosol formation in the tropopause region. One of the dynamical processes that can trigger aerosol formation in the upper troposphere is stratosphere-troposphere exchange (de Reus et al., 1998; Zahn et al., 2000; Khosrawi and Konopka, 2003; Young et al., 2007). However, several observations in the free troposphere showed that new particle formation can also occur in connection with convection and thus vertical motion (e.g. de Reus et al., 1999; Twohy et al., 2002; Benson et al., 2008). Young et al. (2007) e.g. showed that new particle formation events were associated with vertical motion that may have brought higher concentrations of water vapor and aerosol precursors from lower altitudes to higher altitudes where temperatures and surface areas are lower.

The Arctic Study of Tropospheric Aerosol and Radiation (ASTAR) 2004 was conducted from 18 May to 10 June from Longyearbyen, Svalbard, Norway $\left(78^{\circ} \mathrm{N}, 15^{\circ} \mathrm{E}\right)$. This time had been chosen to span the transition period of the boundary layer Arctic aerosol between spring (frequent Arctic haze events) and summer conditions (low influence from anthropogenic sources at lower altitudes). Long-term ground-based observations during this transition period have shown that a systematic change of aerosol properties occurs. This process regularly takes place in a relatively short period during late spring (e.g. Bodhaine, 1989; Ström et al., 2003; Engvall et al., 2008). Details of the campaign as well as some other results deduced from the measurements can be found in e.g. Engvall et al. (2008) and Gayet et al. (2007). Here, we will present microphysical box model simulations of particle formation in the Arctic free troposphere and investigate if vertical motion were involved in the particle formation. Previous studies investigating particle formation due to vertical motion were performed for the midlatitude and tropical regions. Thus, our study is the first one investigating this relationship in the polar regions. We use a microphysical box model which has been developed and applied to investigate the formation and growth of $\mathrm{H}_{2} \mathrm{SO}_{4} / \mathrm{H}_{2} \mathrm{O}$ aerosols in the upper troposphere (Khosrawi and Konopka, 2003; Khosrawi et al., 2006) and lower stratosphere (Blum et al., 2006). Nucleation mode particles were quite frequently observed during ASTAR 2004 at lower altitudes, but only on one occasion (24 May 2004) at higher altitudes (7000 m). Box model simulations were performed for the 24 May as well as for the 22 and 26 May which were representative for non-nucleation events.

\section{ASTAR 2004 campaign}

The aim of the ASTAR 2004 campaign was to investigate aerosol properties in the transition period from Arctic haze to background conditions. Thereby, the main objectives of the campaign were the determination of the vertical structure of the chemical, physical and optical properties of aerosol particles (referring to direct climate effect) as well as the investigation of cloud microphysical properties in the Arctic as a function of different tropospheric aerosol load and the regional extent of aerosol and cloud structures (referring to indirect climate effect). The campaign involved two aircraft, the Polar 2 and the Polar 4. The Polar 2 carried the cloud physics instrumentation as well as an aerosol lidar while the Polar 4 payload was focused on aerosol in situ measurements. The Polar 2 and Polar 4 are research aircraft of the Dornier 228-101 and 228-200 type, respectively, owned by the Alfred Wegener Institute for Polar and Marine Research (AWI) in Bremerhaven and operated by the DLR flight facility department. Both are two-engine turboprop aircraft well capable of operating under the harsh conditions of the polar environment. The aircraft fly at acruising speed of around $80 \mathrm{~m} \mathrm{~s}^{-1}$.

\subsection{In-situ observations}

During the ASTAR 2004 campaign 19 mission flights were performed by the Polar 4 in total. An overview over all flights 
performed during ASTAR 2004 can be found in Engvall et al. (2008) or at the TROLL homepage (http://www.pa.op.dlr.de/ aerosol/troll/t-frame.html). In this study, we use observations performed with the instrumentation from the Atmospheric Science Unit at the Department of Environmental Science (ITM), Stockholm University and from the Institute of Atmospheric Physics at the Deutsches Zentrum für Luft- und Raumfahrt (DLR). From the instruments operated by these two groups, microphysical properties of aerosol particles in the size range from 4 to $3500 \mathrm{~nm}$ were obtained. On board the Polar 4 was a Condensation Particle Counter (CPC, TSI Inc. Model 3010) which was used to obtain the total aerosol number density for particles larger than $10 \mathrm{~nm}$. The aerosol size distribution over the range between 20 and $2200 \mathrm{~nm}$ was derived from simultaneous measurements made with a Differential Mobility Particle Sizer (DMPS, custom made) and an Optical Particle Counter (OPC, GRIMM GmbH 7309).

The uncertainty in the particle number concentration measured by the CPC and OPC instruments depends on the counting statistics or Poisson statistics. The standard deviation is given by the square root of the number of particles counted during a sampling period. The counting error for the CPC is smaller than $1 \%$ for number densities above $100 \mathrm{~cm}^{-3}$ and less than $3 \%$ for concentrations above $10 \mathrm{~cm}^{-3}$. For the OPC, a grand average distribution was calculated, where the average was less than $6 \%$ for sizes smaller than $1000 \mathrm{~nm}$ (Engvall et al., 2008).

Particles with a diameter of 0.31 to $31 \mu \mathrm{m}$ were measured using a Forward Scattering Spectrometer Probe (FSSP-300). Generally, the uncertainty of these measurements is less than $1 \%$ for particles smaller than $2800 \mathrm{~nm}$ and less than $10 \%$ for particles smaller than $15 \mu \mathrm{m}$ (Baumgardner et al., 1992). The FSSP-300 is used in this study only to define the in-cloud sequences during the flights (using a threshold criterion for the number concentration of particles larger than $\approx 3 \mu \mathrm{m}$ ). The number concentration of nucleation mode particles was measured with a Condensation Particle Size Analyzer (CPSA), which measures the particle number densities with a temporal resolution of $1 \mathrm{~s}$. The CPSA is a custom-made multichannel CPC system derived from the TSI 3010 model. The accuracy is estimated to be within 5\%. The instrument consists of four Butanol-operated condensation particle counter modules. During ASTAR 2004 two of the four CPSA modules were operated to determine the total number of particles larger than 4 and larger than $13 \mathrm{~nm}$, thus allowing to infer the number of particles between $4 \mathrm{~nm}$ and $13 \mathrm{~nm}$. The other two channels were used to determine the integrated relative fractions of volatile and non-volatile particles larger than $13 \mathrm{~nm}$.

CPSA derived number concentrations were corrected for coincidence effects and efficiencies determined in the laboratory. Corrections for diffusion losses of small particles in the tubing systems have not been made because this requires accurate knowledge on the size distribution in the ultrafine size range. One can estimate however that less than $10 \%$ of particles of $10 \mathrm{~nm}$ size and about $35 \%$ of particles of $4 \mathrm{~nm}$ size may get lost in the sampling system due to diffusion losses.

During the ASTAR 2004 campaign nucleation mode particles were quite frequently observed at altitudes below $4000 \mathrm{~m}$. However, in the upper free troposphere nucleation mode particles were only observed once, namely on 24 May. On 24 May nucleation mode particles (4 to $13 \mathrm{~nm}$ ) were observed with the CPSA in the free troposphere at an altitude of $\approx 7000 \mathrm{~m}$ (around 09:00 UTC). The flight on 24 May 2004 was performed in the morning from 06:45 to 09:45 UTC under clear sky conditions. Particle numbers of nucleation mode particles measured during that flight were about a few hundred particles per $\mathrm{cm}^{3}$ (Fig. 1). The flight on 24 May 2004 was performed in the area of Storfjoden. The flights before and after this flight with the nucleation event were performed on 22 May and 26 May, respectively. On 22 May the flight was performed in the vicinity of $\mathrm{Ny}$ Ålesund while the flight on 26 May was performed down stream of Svalbard (during both flights some low clouds were present; low scattered clouds on 22 May and astratus layer on 26 May). The flight tracks for these three flights are shown in Fig. 2.

\section{Microphysical box model}

A microphysical aerosol box model was used to investigate if the binary homogeneous nucleation of $\mathrm{H}_{2} \mathrm{SO}_{4} / \mathrm{H}_{2} \mathrm{O}$ aerosols could have produced the nucleation mode particles observed on 24 May 2004 during the ASTAR 2004 campaign. The assumption that the particles could have been formed by the binary homogeneous nucleation of $\mathrm{H}_{2} \mathrm{SO}_{4}$ and $\mathrm{H}_{2} \mathrm{O}$ is reasonable since it has been shown previously that observations of particle formation can be well explained by binary homogeneous nucleation above $4 \mathrm{~km}$ (Weber et al., 1999). The processes implemented in the microphysical box model are besides the binary homogeneous nucleation of $\mathrm{H}_{2} \mathrm{SO}_{4}$ and $\mathrm{H}_{2} \mathrm{O}$, the Brownian coagulation and the diffusive uptake of $\mathrm{H}_{2} \mathrm{O}$ and nitric acid $\left(\mathrm{HNO}_{3}\right)$ on the liquid aerosol particle. The uptake of $\mathrm{HNO}_{3}$ and $\mathrm{H}_{2} \mathrm{O}$ by the liquid aerosol particles is calculated by solving the growth and evaporation equation (Pruppacher and Klett, 1978) and using the parameterisation of Luo et al. (1995) for the partial pressures of $\mathrm{H}_{2} \mathrm{O}$ and $\mathrm{HNO}_{3}$. The binary homogeneous nucleation rate is calculated as described by Kärcher (1998) by using a revised form (Jaecker-Voirol et al., 1987) with corrections due to the formation of gaseous sulfuric acid hydrates (Laaksonen and Kulmala, 1991). The coagulation of aerosol particles is calculated by using the coagulation kernel of Fuchs (1977). Owing to the coupled uptake of $\mathrm{H}_{2} \mathrm{O}$ and $\mathrm{HNO}_{3}$, the $\mathrm{H}_{2} \mathrm{SO}_{4}$ in the particles is considered as passive while the $\mathrm{H}_{2} \mathrm{O}$ and $\mathrm{HNO}_{3}$ are considered as active components. The condensation of $\mathrm{H}_{2} \mathrm{SO}_{4}$ on the preexisting $\mathrm{H}_{2} \mathrm{SO}_{4} / \mathrm{H}_{2} \mathrm{O}$ aerosol is not considered in the box model. However, this should not affect our results since condensation is a very slow process. The 


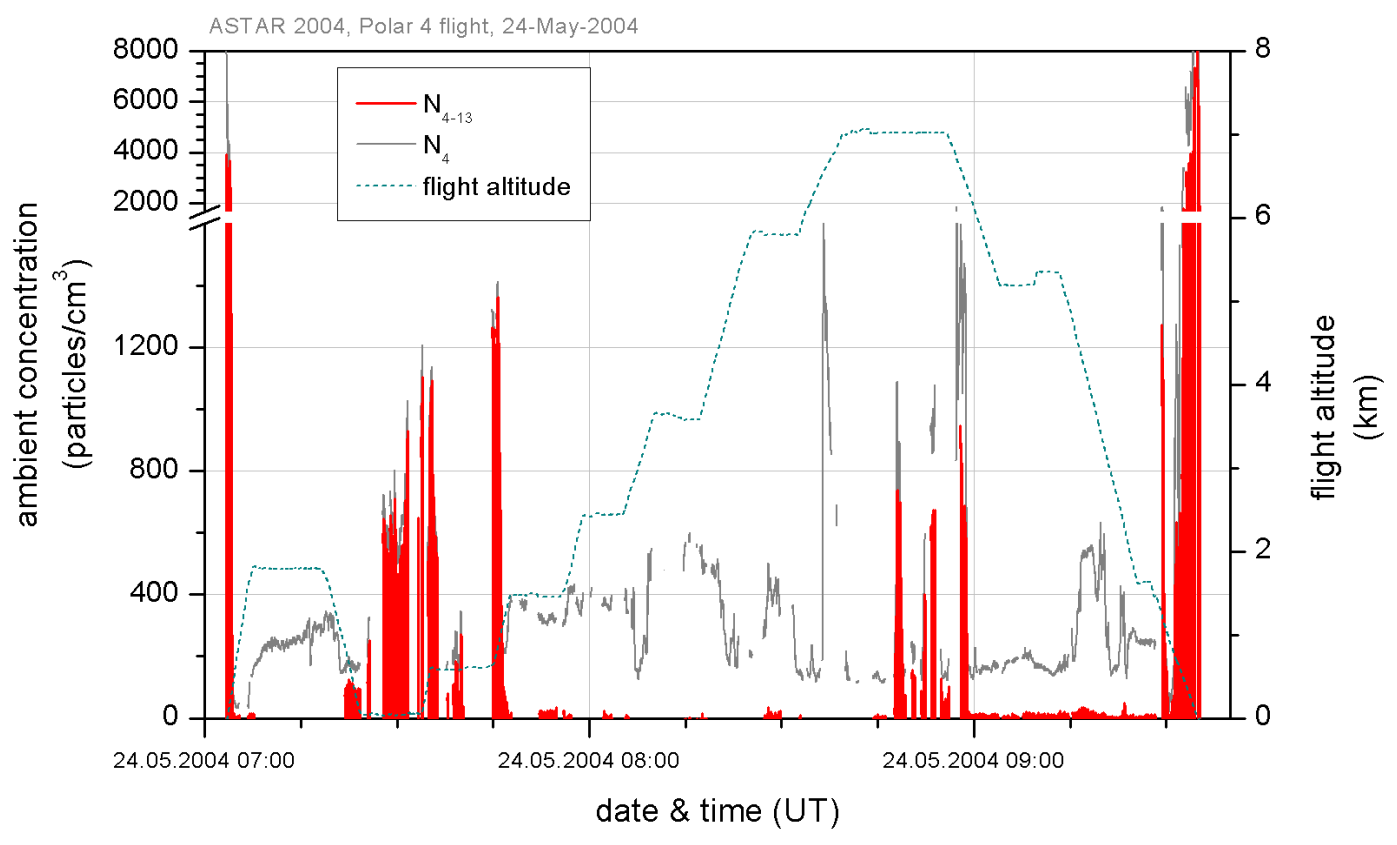

Fig. 1. Nucleation mode particles ( 4 to $13 \mathrm{~nm}$ ) measured on 24 May 2004 during the ASTAR 2004 campaign. Nucleation mode particles were measured at $7000 \mathrm{~m}$ between 08:45 and 09:00 UTC. The measured nucleation mode particles at the beginning and end of the measurement (07:05 and 09:30 UTC, respectively) occurred in the boundary layer. Note: The gaps in the figure are due to elimination of data when the aircraft was turning (high bank angle).

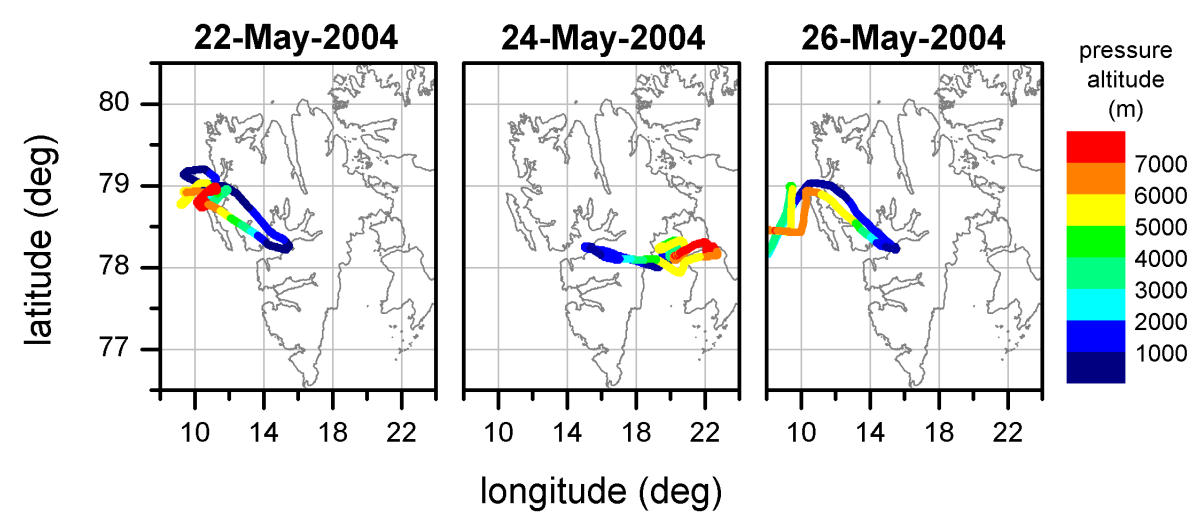

Fig. 2. Flight tracks of the flights performed on 22 May (left), 24 May (middle) and 26 May (right).

atmospheric concentrations of $\mathrm{H}_{2} \mathrm{SO}_{4}$ are much lower than the concentrations of $\mathrm{H}_{2} \mathrm{O}$, so that rather $\mathrm{H}_{2} \mathrm{O}$ will condense onto the particles than $\mathrm{H}_{2} \mathrm{SO}_{4}$ (Hamill et al., 1997). Further, since the concentration of $\mathrm{H}_{2} \mathrm{SO}_{4}$ is decreasing with altitude we can assume that $\mathrm{H}_{2} \mathrm{SO}_{4}$ condensation is more important for aerosol growth in the lower troposphere than in the upper troposphere. Furthermore, Kerminen and Kulmala (2002) have shown that after a nucleation burst coagulation is the more dominant process affecting the aerosol size distribution than condensation.

The box model is initialized with a particle ensemble that contains pure $\mathrm{H}_{2} \mathrm{SO}_{4} / \mathrm{H}_{2} \mathrm{O}$ aerosols. The $\mathrm{H}_{2} \mathrm{O}$ in the aerosol particle is assumed to be always in equilibrium with the surrounding air. The considered particle ensemble is divided geometrically into $\mathrm{N}$ radial size bins. Therefore, the size width bin increases exponentially, which has the advantage that the required wide range of particle dimensions can be covered with a fair resolution (Kärcher, 1998). The aerosol number density in the size bins is calculated by using a lognormal distribution. For each size bin, the time evolution is calculated along air parcel trajectories considering nucleation, coagulation and condensation processes. The model equations set up a nonlinear, coupled system of ordinary differential equations which are solved using a semi-implicit Euler method (Deuflhard, 1985). 


\subsection{Air parcel trajectories}

Air parcel trajectories were calculated by the Royal Netherlands Meteorological Institute (KNMI) backwards for 6- d based on ECMWF analyses with TRAJKS (Scheele et al., 1996; Stohl et al., 2001) using a time resolution of $\Delta t=1 \mathrm{~h}$. On 24 May the trajectory was started at 09:00 UTC at $22.5^{\circ} \mathrm{E} / 78.2^{\circ} \mathrm{N}$ at two altitudes $(6000$ and $7000 \mathrm{~m})$. These two altitudes were selected to cover the altitude range over which nucleation took place. Additionally, trajectories were calculated starting on 22 May (09:30 UTC $\left.11.0^{\circ} \mathrm{E} / 78.9^{\circ} \mathrm{N}\right)$ and 26 May (16:00 UTC $\left.10.0^{\circ} \mathrm{E} / 78.5^{\circ} \mathrm{N}\right)$. These days are representative for days without observation of nucleation mode particles. The path of these three trajectories (22, 24 and 26 May, $7000 \mathrm{~m}$ ) are shown in Fig. 3. Further, trajectories were calculated starting at the following coordinates which represent a grid over the measurement area: $10.0^{\circ} \mathrm{E} / 77.0^{\circ} \mathrm{N}, 10.0^{\circ} \mathrm{E} / 80.5^{\circ} \mathrm{N}$, $28.0^{\circ} \mathrm{E} / 80.5^{\circ} \mathrm{N}, 28.0^{\circ} \mathrm{E} / 77.0^{\circ} \mathrm{N}$ and $19.0^{\circ} \mathrm{E} / 78.7^{\circ} \mathrm{N}$. The purpose of this grid was to investigate nucleation properties also in the surroundings of the measurement area. In total 36 back trajectories ( 3 measurement days $\times 2$ altitudes $\times 6$ coordinates) were calculated with TRAJKS. Additionally to temperature and pressure the following parameters were available along the trajectories provided by KNMI: moisture mixing ratio, liquid water content and ice water content, cloud fraction, dry stability and wet stability. Additionally to these parameters the updraft velocity and the cooling rate were calculated along the back trajectories. The dry stability is defined as the change of potential temperature $\Theta$ with altitude while the wet stability is defined as change of the equivalent potential temperature $\Theta_{e}$ with altitude (using pressure $p$ as vertical coordinate). Dry and wet stability $\left(\gamma_{d}=\frac{d \Theta}{d p}\right.$ and $\left.\gamma_{w}=\frac{d \Theta_{e}}{d p}\right)$ are used here as a proxy to investigate if vertical motion have occurred along the back trajectories and if vertical motion were involved in the formation of new particles.

A neutral or unstable atmosphere will cause an updraft and thus acooling of the air parcel while a stable atmosphere will tend to inhibit vertical motion and thus keep the air parcel at its original position. A stable atmosphere is defined by $\frac{d \Theta}{d p}>0$ and $\frac{d \Theta_{e}}{d p}>0$, respectively, while for a neutral atmosphere $\frac{d \Theta}{d p}=0$ and $\frac{d \Theta_{e}}{d p}=0$, respectively, and for an unstable atmosphere $\frac{d \Theta}{d p}<0$ and $\frac{d \Theta_{e}}{d p}<0$, respectively.

\section{Results}

\subsection{Box model simulations}

The box model simulations were performed along the trajectories started on 24 May 2004, the day with the nucleation event as well as for the days before and after (22 and 26 May 2004) which were representative for non-nucleation events. The simulations were performed with the same time

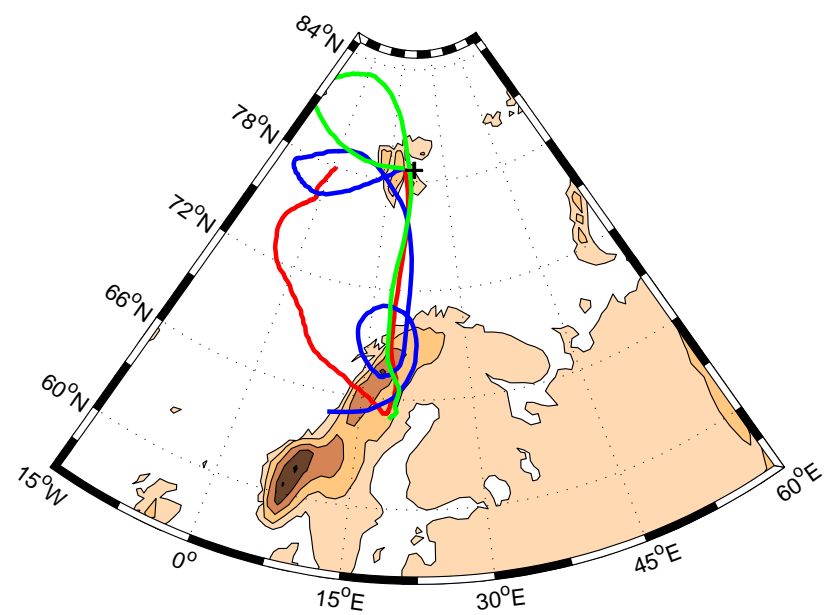

Fig. 3. Back trajectories calculated with TRAJKS based on ECWMF analyses. The trajectories that were started at $7000 \mathrm{~m}$ on 22 May at $09: 30 \mathrm{UTC}$ at $11.0^{\circ} \mathrm{E} / 78.9^{\circ} \mathrm{N}$ (red), 24 May at 09:00 UTC at $22.5^{\circ} \mathrm{E} / 78.2^{\circ} \mathrm{N}$ (blue) and 26 May at 16:00 UTC $10.0^{\circ} \mathrm{E} / 78.5^{\circ} \mathrm{N}$ (green) are shown.

resolution as for the air parcel trajectories $(\Delta t=1 \mathrm{~h})$. The processes that are considered in the box model simulations performed here are nucleation and coagulation. Note, the trajectories were calculated backwards in time, but the model simulations are performed forward in time, thus, the ending point of the trajectory is the start point of the simulation and the simulation ends at the time and the location where the back trajectories were started. The box model was initialized with aerosol distributions taken from the in-situ measurements made with the DMPS during the flights on 22, 24 and 26 May 2004 at 6000 and $7000 \mathrm{~m}$ (which represents the background aerosol distribution). Thereby, log-normal size distributions were fitted to these data. The aerosol size distributions used for initialization of the box model were divided into 46 size bins with total particle number densities of $n=50-350 \mathrm{~cm}^{-3}$, distribution widths of $\sigma=1.8-1.9$ and mean diameters of $d_{m}=60-140 \mathrm{~nm} .{ }^{1}$ The $\mathrm{H}_{2} \mathrm{O}$ mixing ratios were derived from radiosonde soundings over $\mathrm{Ny}$ Ålesund, Svalbard $\left(\mu_{\mathrm{H}_{2} \mathrm{O}}=154 \mathrm{ppmv}\right.$ and $150 \mathrm{ppmv}$ at $6000 \mathrm{~m}$ on 22 and 26 May, respectively, $\mu_{\mathrm{H}_{2} \mathrm{O}}=78 \mathrm{ppmv}$ and $98 \mathrm{ppm}$ at $7000 \mathrm{~m}$ on 22 and 26 May, respectively, and $\mu_{\mathrm{H}_{2} \mathrm{O}}=117 \mathrm{ppmv}$ at $6000 \mathrm{~m}$ on 24 May and $\mu_{\mathrm{H}_{2} \mathrm{O}}=219 \mathrm{ppmv}$ at $7000 \mathrm{~m}$ on 24 May). Measurements of $\mathrm{H}_{2} \mathrm{SO}_{4}$ mixing ratios were not performed and is thus a unknown variable in this study.

\footnotetext{
${ }^{1}$ Note, the initialization with the measured aerosol size distributions is done six days before the measurements actually were performed. However, for obtaining an agreement between model simulations and measurements an additional requirement besides the agreement of the modeled and measured nucleation mode particles is that at the end of the simulation also the background aerosol distribution is in agreement with the measured aerosol size distribution.
} 

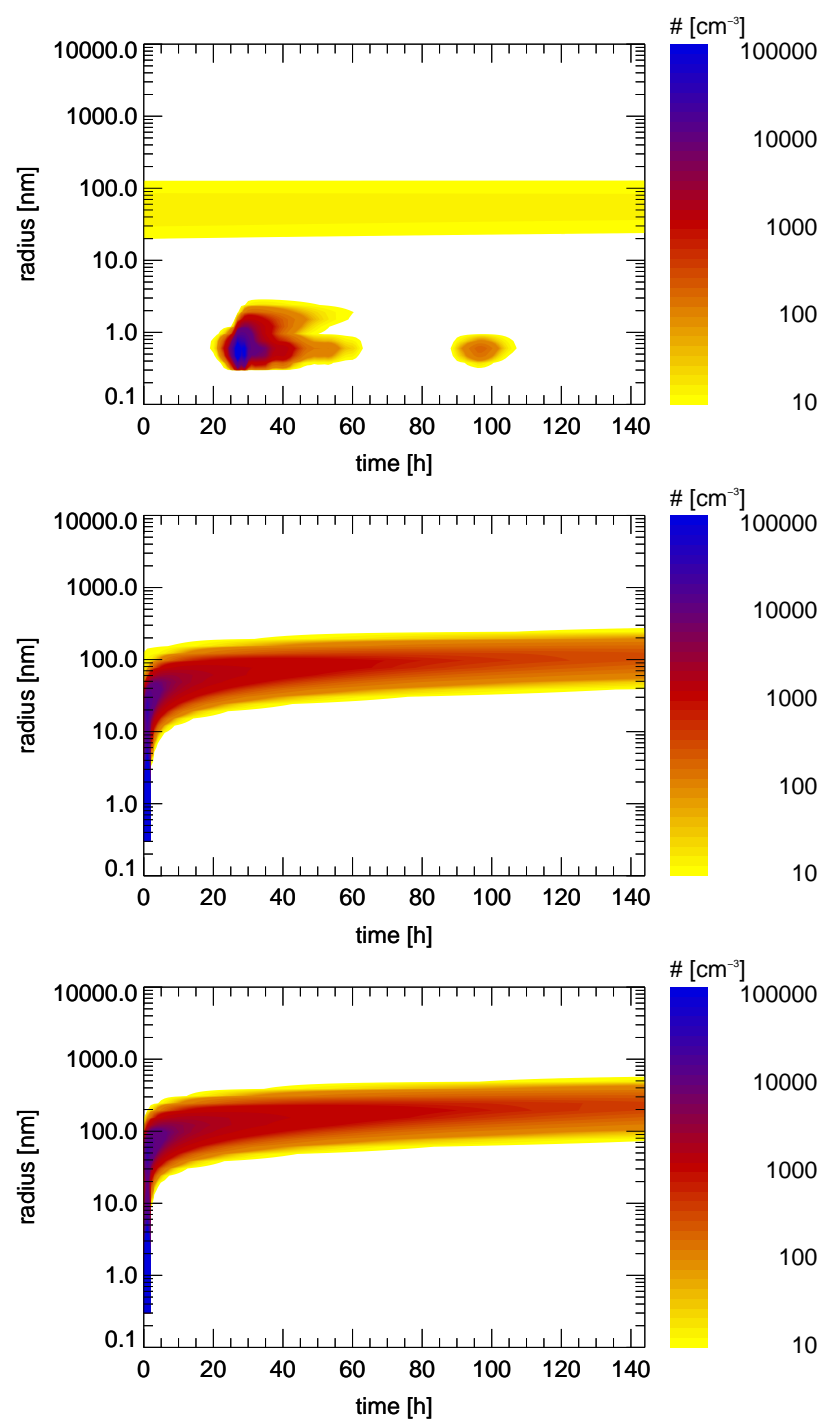

Fig. 4. Number density versus time for the simulation along the back trajectory started on 24 May at $6000 \mathrm{~m}\left(19.0^{\circ} \mathrm{E}, 78.7^{\circ} \mathrm{N}\right)$ initializing the model with a $\mathrm{H}_{2} \mathrm{SO}_{4}$ mixing ratio of $1 \mathrm{pptv}$ (top), $40 \mathrm{pptv}$ (middle) and $80 \mathrm{pptv}$ (bottom). The nucleation burst occurs at $t=28 \mathrm{~h}(1 \mathrm{pptv}), t=2 \mathrm{~h}(40 \mathrm{pptv})$ and $t=2 \mathrm{~h}(80 \mathrm{pptv})$ and thus this model simulation can be classified as case 2 . See text for further details. (Note: The simulations are performed forward in time, thus, the end of the simulations coincides with the starting point of the back trajectory).

Measurements of sulfuric acid are rare and large-scale measurements from satellites or from a ground-based network are not available. The only existing measurements of sulfuric acid are the ones derived from balloon, aircraft or groundbased measurements during measurement campaigns. Measurements in the free troposphere were performed e.g. in the vicinity of Tenerife during the Aerosol Characterization Experiment (ACE 2). These measurements show that the aerosol $\mathrm{H}_{2} \mathrm{SO}_{4}$ mixing ratios was typically between 10 and
120 pptv, but can reach up to 550 pptv (Curtius et al., 2001). However, during this campaign only the aerosol sulfuric acid was measured and not the gas phase sulfuric acid. Gas phase sulfuric acid concentrations are typically much lower and range between $10^{5}$ to $10^{7}$ molecules $\mathrm{cm}^{-3}$ in clean air (e.g. Eisele and Tanner, 1993) and up to $10^{8}$ molecules $\mathrm{cm}^{-3}$ for polluted air (Berresheim et al., 2002; Bardouki et al., 2003).

The simulations were performed along the 36 trajectories for three different gas phase sulfuric acid mixing ratios $\mu_{\mathrm{H}_{2} \mathrm{SO}_{4}}=1,40$ and 80 pptv $\left(1 \mathrm{pptv}=2.67 \times 10^{7}\right.$ molecules $\mathrm{cm}^{-3}$ at $0^{\circ} \mathrm{C}$ and $1013 \mathrm{hPa}$ ), where a mixing ratio of $\mu_{\mathrm{H}_{2} \mathrm{SO}_{4}}=1 \mathrm{pptv}$ is representative for clean air and mixing ratios of $\mu_{\mathrm{H}_{2} \mathrm{SO}_{4}}=40$ and $80 \mathrm{pptv}$ are representative for polluted air. ${ }^{2}$ Performing all these simulations ( 36 trajectories $\times 3$ sulfuric acid mixing ratios $=108$ simulations) we could divide the results into three cases: (1) Nucleation occurred always at the same time step $t=2 \mathrm{~h}$ (19 occurrences) independent which sulfuric acid mixing ratio was used. Here, nucleation occurred always immediately due to temperatures which were sufficiently low to initiate nucleation $(T<235 \mathrm{~K}$ at $t=1 \mathrm{~h}$ ). (2) Nucleation occurred at the same time step ( $t=2 \mathrm{~h}$ ) when $\mathrm{H}_{2} \mathrm{SO}_{4}$ mixing ratios of $\mu_{\mathrm{H}_{2} \mathrm{SO}_{4}}=40$ pptv and $\mu_{\mathrm{H}_{2} \mathrm{SO}_{4}}=80$ pptv were used (7 occurrences), but nucleation occurred at a different time step (e.g. $t=12 \mathrm{~h}$ ) when a $\mathrm{H}_{2} \mathrm{SO}_{4}$ mixing ratio of $\mu_{\mathrm{H}_{2} \mathrm{SO}_{4}}=1 \mathrm{pptv}$ was used $(T<250 \mathrm{~K}$, thus significantly higher temperatures than for case 1). (3) Nucleation occurred for all sulfuric acid mixing ratios used at different time steps e.g. for $\mu_{\mathrm{H}_{2} \mathrm{SO}_{4}}=1 \mathrm{pptv}$ at $t=17 \mathrm{~h}$, for $\mu_{\mathrm{H}_{2} \mathrm{SO}_{4}}=40 \mathrm{pptv}$ at $t=16 \mathrm{~h}$ and for $\mu_{\mathrm{H}_{2} \mathrm{SO}_{4}}=80 \mathrm{pptv} t=2 \mathrm{~h}$ (10 occurrences). Here, temperatures were between 255 and $270 \mathrm{~K}$ at $t=1 \mathrm{~h}$ but decreased down to temperatures between 240 and $230 \mathrm{~K}$ along the trajectory. Figure 4 shows the simulation for the trajectory started on 24 May at $6000 \mathrm{~m}\left(19.0^{\circ} \mathrm{E} / 78.7^{\circ} \mathrm{N}\right)$ which is representative for case 2. Along this trajectory the nucleation burst occurred at $t=25 \mathrm{~h}$ for an initial $\mathrm{H}_{2} \mathrm{SO}_{4}$ mixing ratio of $1 \mathrm{pptv}$ and at $t=2 \mathrm{~h}$ for an initial $\mathrm{H}_{2} \mathrm{SO}_{4}$ mixing ratios of 40 pptv and 80 pptv. While for case 1 the temperature was the only driving mechanism, for case 2 and 3 vertical motion could have influenced the formation of new particles. In fact, that vertical motion can influence particle formation has been previously been observed (e.g. de Reus et al., 1999; Twohy et al., 2002; Benson et al., 2008). As can be seen from the frequency of occurrence given in the brackets, the majority of cases could be classified to case 1 (see also Table 2). Thus, new particle formation was in this case study most frequently initiated by sufficiently cold temperatures.

\footnotetext{
${ }^{2}$ It should be noted here that the mixing ratios we used for being representative for polluted air are on the higher range of previously measured concentrations.
} 

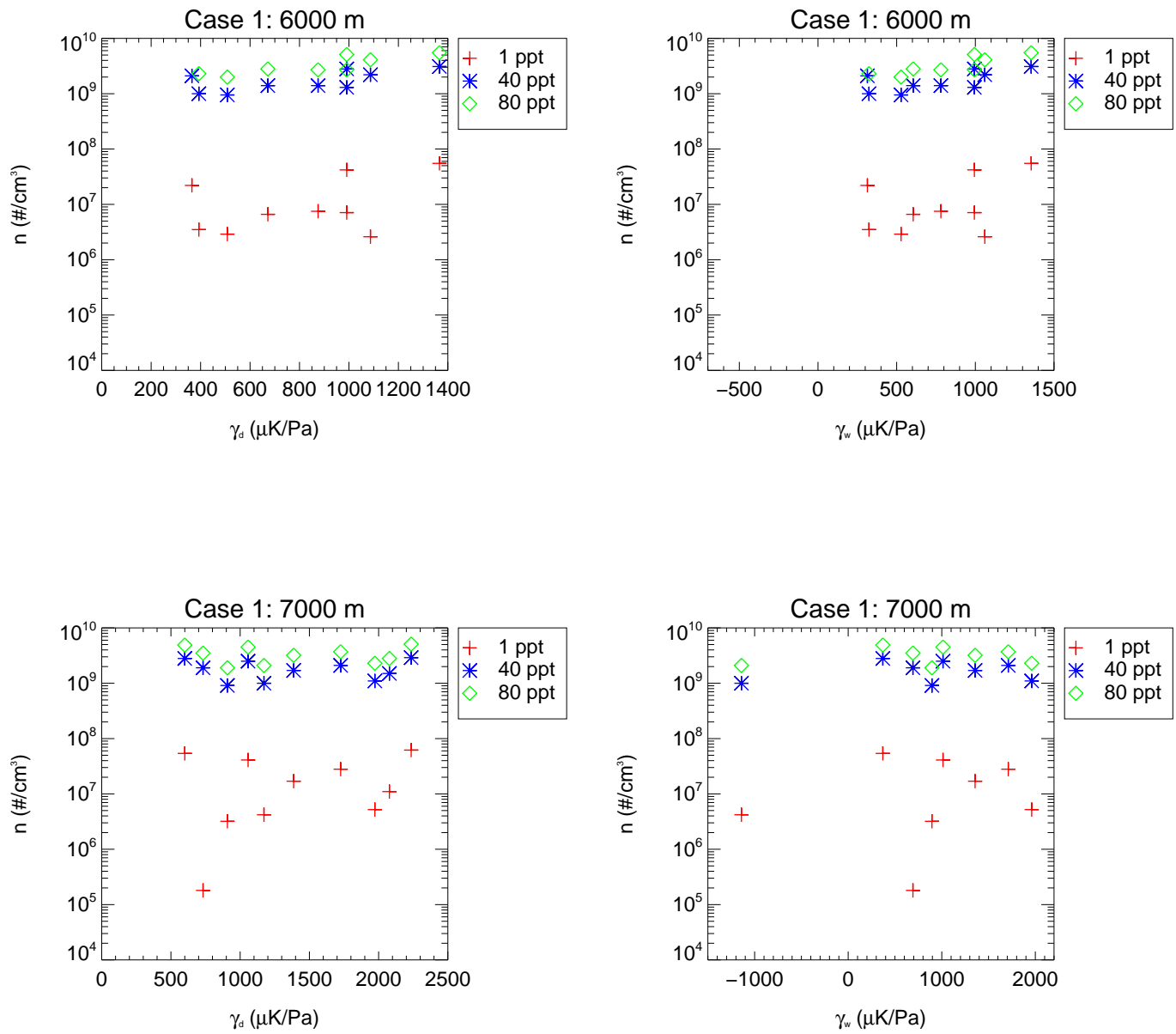

Fig. 5. The maximum number density encountered during the simulation versus the dry stability $\gamma_{d}$ (left) and wet stability $\gamma_{w}$ (right) for $6000 \mathrm{~m}$ (top) and $7000 \mathrm{~m}$ (bottom) for the simulations which have been classified to case 1 . The box model simulations were initialized with a $\mathrm{H}_{2} \mathrm{SO}_{4}$ mixing ratio of 1 pptv (red), 40 pptv (blue) and 80 pptv (green).

\subsubsection{Relationship between $n$ and $\gamma_{w}, \gamma_{d}$ and $w$}

Here, we use atmospheric stability and vertical velocity, which were derived additionally to temperature and pressure along the trajectories, to investigate if vertical motion were involved in the particle formation. Figures 5 to 7 show the number concentration $n$ (here the maximum number concentration of freshly nucleated particles encountered during the simulation) versus the corresponding dry $\gamma_{d}$ (left) and wet stability $\gamma_{w}$ (right) for the trajectories started at $6000 \mathrm{~m}$ (top) and $7000 \mathrm{~m}$ (bottom). For case 1 (Fig. 5) the number concentration $n$ is uniformly distributed with $\gamma_{d}$ and $\gamma_{w}$ at both altitudes. The number concentration is solely increasing for increasing $\mathrm{H}_{2} \mathrm{SO}_{4}$ mixing ratios. The values for $\gamma_{d}$ and $\gamma_{w}$ were with one exception greater than zero $(6000 \mathrm{~m}$ and $7000 \mathrm{~m}$ ) which can be attributed to a stable stratification in relation to dry and wet air. The exception is found at $7000 \mathrm{~m}$ (Fig. 5, bottom right) with a $\gamma_{w}$ lower than zero and thus an unstable stratification. Thus, it seems that for case 1 the stability of the atmosphere did not contribute to the particle formation. Here, except for one occurrence particle formation occurred during a stable stratification of the atmosphere thus indicating that vertical motion were not involved in the particle formation. This uniformity agrees with the behavior we found for case 1 from the box model simulations showing that nucleation occurred always at the same time step and that the temperature only was the driving force.

For case 2 (Fig. 6) the number densities are generally lower than for case 1 (ranging between $10^{5}-10^{9} \mathrm{~cm}^{-3} \mathrm{com}$ pared to $10^{6}-10^{10} \mathrm{~cm}^{-3}$ for case 1). Case 2 was more frequently occurring at $6000 \mathrm{~m}$ than at $7000 \mathrm{~m}$. For a $\mathrm{H}_{2} \mathrm{SO}_{4}$ mixing ratio of $1 \mathrm{pptv} n$ is uniformly distributed at $6000 \mathrm{~m}$ as for case 1 (Fig. 6 top). However, for a $\mathrm{H}_{2} \mathrm{SO}_{4}$ mixing ratio of $1 \mathrm{pptv}$ at $7000 \mathrm{~m}$ a slight decrease with increasing $\gamma_{d}$ and $\gamma_{w}$ is visible. This decrease is at $7000 \mathrm{~m}$ also visible for $\mathrm{H}_{2} \mathrm{SO}_{4}$ mixing ratios of 40 and $80 \mathrm{pptv}$. However, since we only have two data points for each sulfuric acid mixing ratio it is difficult to say if this relation is arbitrarily. At $6000 \mathrm{~m}$ an increase with a subsequent decrease is found (thus a slope) for $\mathrm{H}_{2} \mathrm{SO}_{4}$ mixing ratios of 40 and $80 \mathrm{pptv}$. The values for 

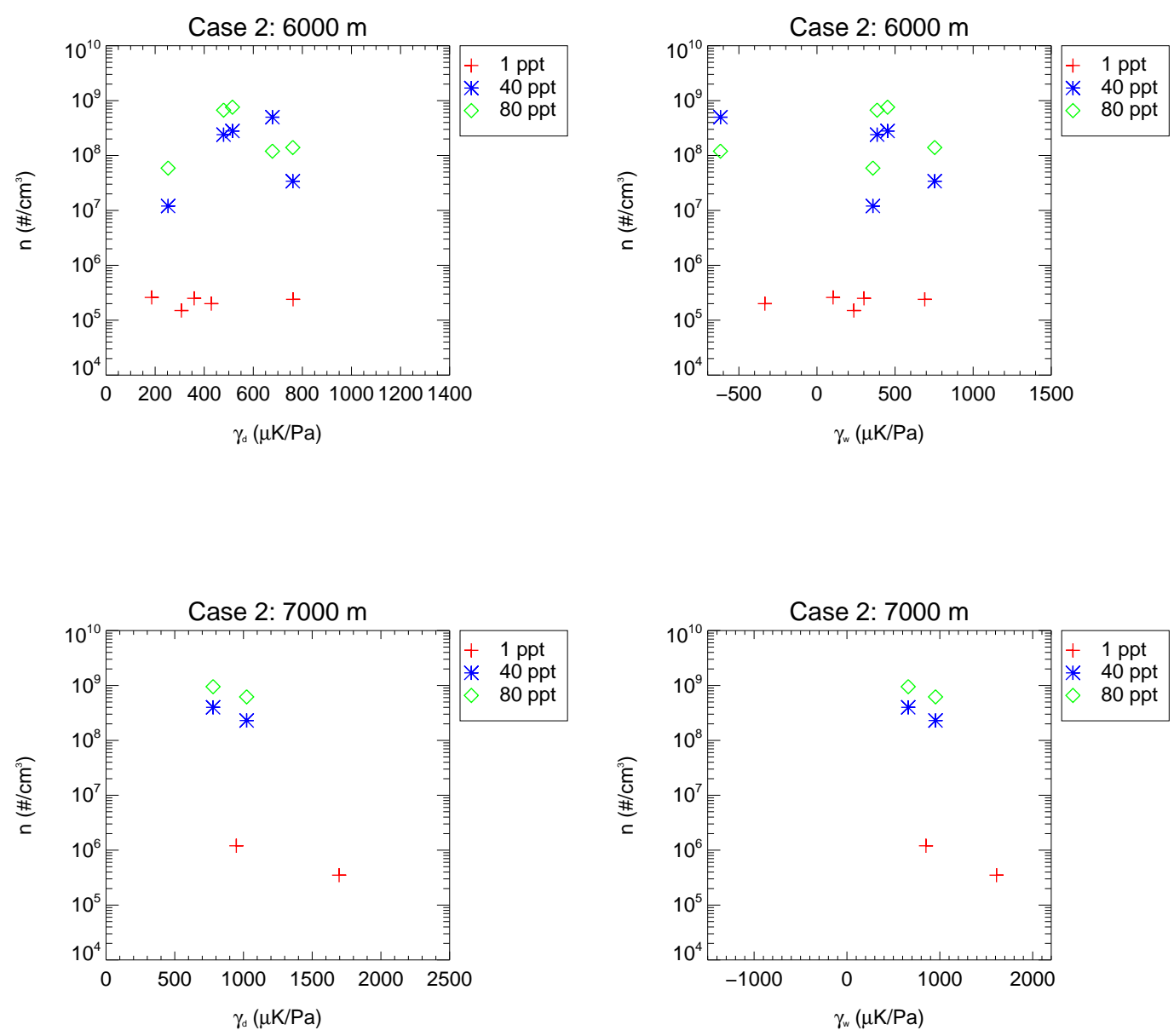

Fig. 6. The maximum number density encountered during the simulation versus the dry stability $\gamma_{d}$ (left) and wet stability $\gamma_{w}$ (right) for $6000 \mathrm{~m}$ (top) and $7000 \mathrm{~m}$ (bottom) for the simulations which have been classified to case 2 . The box model simulations were initialized with a $\mathrm{H}_{2} \mathrm{SO}_{4}$ mixing ratio of 1 pptv (red), 40 pptv (blue) and $80 \mathrm{pptv}$ (green).

$\gamma_{d}$ and $\gamma_{w}$ are somewhat lower than for case 1 but still positive. This relationship reflects case 2 as defined from the box model simulations where nucleation occurred at different time steps for 1 pptv $\mathrm{H}_{2} \mathrm{O}_{4}$ but at $t=2$ for 40 and $80 \mathrm{pptv}$ $\mathrm{H}_{2} \mathrm{SO}_{4}$. Thus, for 1 pptv vertical motion could have been involved in the particle formation while for 40 and $80 \mathrm{pptv}$ sufficiently high sulfuric acid mixing ratio was provided to trigger particle formation.

The number densities are even lower for case 3 (Fig. 7) than for case 2 and case 1 and also the dry and wet stabilities are lower (centered around zero and also encountering negative values). A uniform distribution is not visible and also no other structure between $\gamma_{d}$ or $\gamma_{w}$ and $n$ is visible in this figure (Fig. 7). This relationship reflects the one defined from the box model simulations as case 3 where nucleation occurred for each sulfuric acid mixing ratio that has been used for the simulations at a different time step. Thus, for case 3 it seems that vertical motion were generally involved in the particle formation independent of which sulfuric acid mixing ratio was used.

The simulated number densities $n$ versus vertical velocity $w$ are shown for case 1 to case 3 in Fig. 8. For the vertical velocity a similar behavior as for the dry and wet stability is found. Case 1 is uniformly distributed with regard to the updraft velocity while for case 2 a uniform distribution is only found at $6000 \mathrm{~m}$ for a sulfuric acid mixing ratio of 1 pptv. For sulfuric acid mixing ratios of 40 and $80 \mathrm{pptv}$ an increase with a subsequent decrease is found for $n$. At $7000 \mathrm{~m}$ case 2 shows a decrease for 1 pptv and increase of $n$ with $w$ for 40 and 80 pptv. However, since we only have two data points for each sulfuric acid mixing ratio it is difficult to say if this relation is only arbitrarily. Case 3 is extending over a larger range of vertical velocities (from -2 to $+6 \mathrm{~m} / \mathrm{s}$ ) as the other two cases at both altitudes showing that for this case the influence of vertical motion was strongest. In Table 1 the results are summarized by giving the range of values of $\gamma_{d}$, 

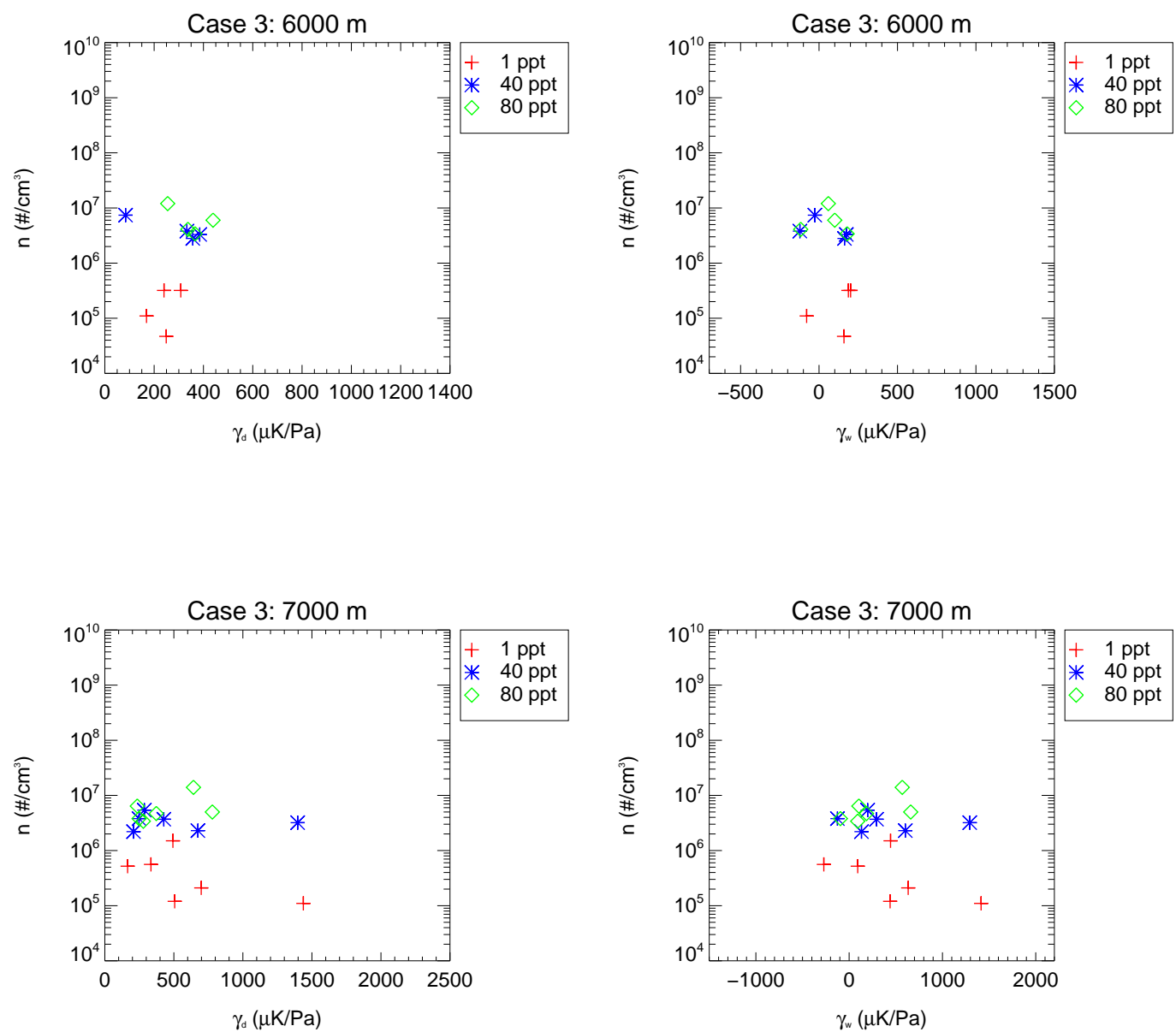

Fig. 7. The maximum number density encountered during the simulation versus the dry stability $\gamma_{d}$ (left) and wet stability $\gamma_{w}$ (right) for $6000 \mathrm{~m}$ (top) and $7000 \mathrm{~m}$ (bottom) for the simulations which have been classified to case 3 . The box model simulations were initialized with a $\mathrm{H}_{2} \mathrm{SO}_{4}$ mixing ratio of $1 \mathrm{pptv}$ (red), 40 pptv (blue) and $80 \mathrm{pptv}$ (green).

$\gamma_{w}, w$ and $n$ for the three cases at both altitudes considered. Thereby, an decrease from case 1 to case 3 is found for $\gamma_{d}$ and $\gamma_{w}$ while for $w$ an increase in the values as well as a broader value range is found. The particle number densities are decreasing and asmaller range of values is found from case 1 to case 3 . Thus, with decreasing strength of stability (from stable to neutral-unstable) stronger vertical motion are encountered.

Considering the above described relationships between the number concentration $n$ and the dry and wet stability $\gamma_{w}$ and $\gamma_{d}$, vertical velocity $w$ and the temperatures encountered during the simulation (see previous section), it appears that for case 1 the temperature alone is the driving force for new particle formation, while for case 2 and case 3 vertical motion could have been involved in the formation of the new particles. Table 2 shows the occurrence of the three cases separated into the three days of the ASTAR 2004 campaign and the two levels considered here $(6000$ and $7000 \mathrm{~m})$. Case 1 is the case that in total most frequently occurred
Table 1. Range of values of $\gamma_{d}, \gamma_{w}, w$ and $n$ for case 1 to case 3 for the two altitudes (6000 and $7000 \mathrm{~m}$ ) considered.

\begin{tabular}{lcrrcl}
\hline Case & Altitude & $\gamma_{d}(\mu \mathrm{K} / \mathrm{Pa})$ & $\gamma_{w}(\mu \mathrm{K} / \mathrm{Pa})$ & $w(\mathrm{~cm} / \mathrm{s})$ & $n\left(\mathrm{~cm}^{-3}\right)$ \\
\hline Case 1 & 6000 & $400-1400$ & $300-1400$ & $-2-2$ & $10^{6}-10^{10}$ \\
Case 2 & 6000 & $200-800$ & $-500-700$ & $-3-4$ & $10^{5}-10^{9}$ \\
Case 3 & 6000 & $20-400$ & $-100-200$ & $-2-6$ & $10^{4}-10^{7}$ \\
\hline Case 1 & 7000 & $500-2300$ & $400-2000$ & $-2-4$ & $10^{5}-10^{10}$ \\
Case 2 & 7000 & $700-1700$ & $700-1600$ & $-4-2$ & $10^{5}-10^{9}$ \\
Case 3 & 7000 & $20-1500$ & $-300-1400$ & $-3-5.5$ & $10^{4}-10^{7}$ \\
\hline
\end{tabular}

(19 occurrences), followed by case 3 (10 occurrences) and case 2 ( 7 occurences). Considering each day, the 26 May was dominated by case 1 in both altitudes while the 22 May was dominated by case 3 at $6000 \mathrm{~m}$ and to the same amount by case 1 and case 3 at $7000 \mathrm{~m}$. The 24 May was dominated 

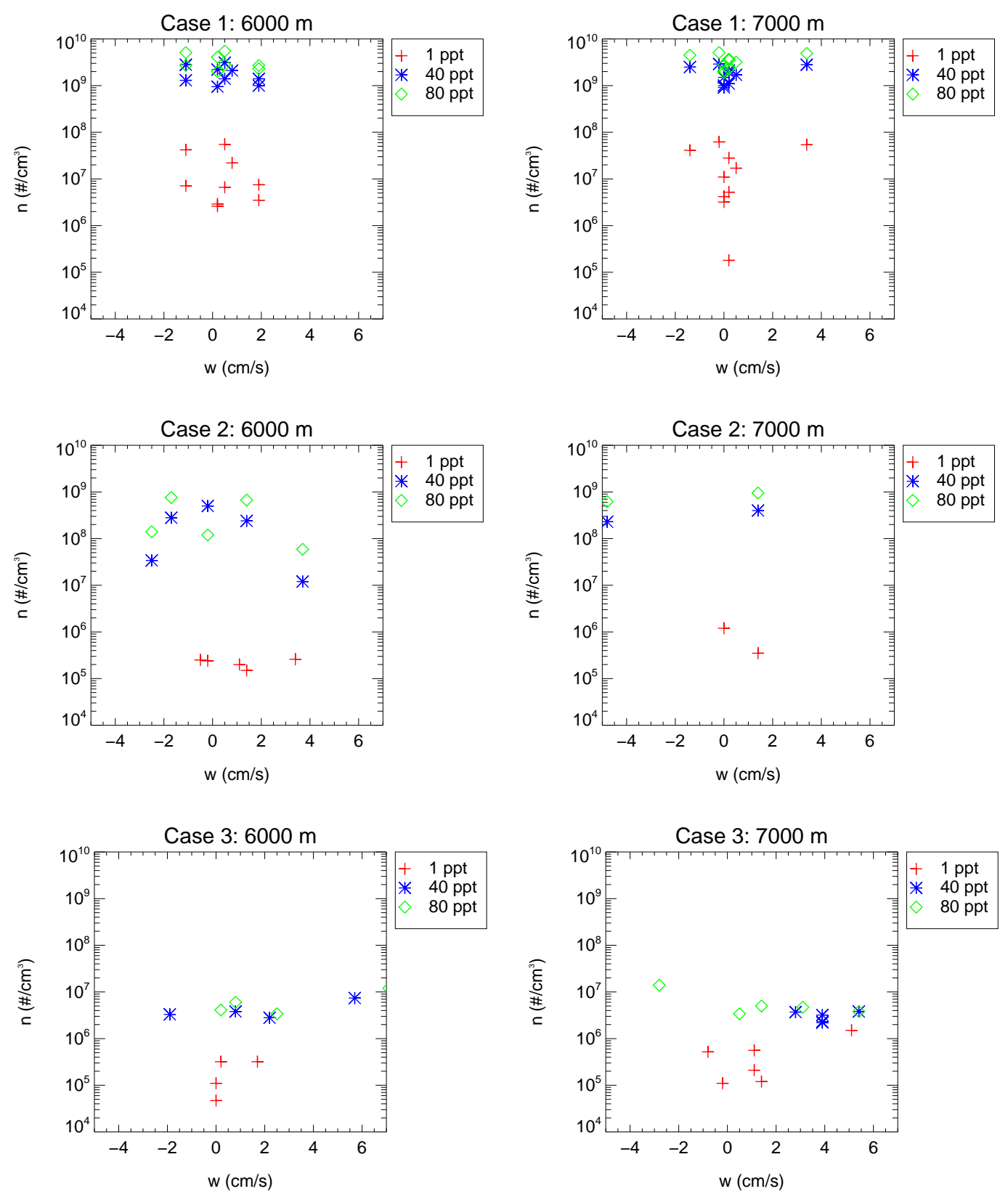

Fig. 8. The maximum number density encountered during the simulation versus updraft velocity $w$ for $6000 \mathrm{~m}$ (left) and $7000 \mathrm{~m}$ (right) for the simulations which have been classified to case 1 (top), case 2 (middle), and case 3 (bottom). The box model simulations were initialized with a $\mathrm{H}_{2} \mathrm{SO}_{4}$ mixing ratio of $1 \mathrm{pptv}$ (red), $40 \mathrm{pptv}$ (blue) and $80 \mathrm{pptv}$ (green).

by case 2 at $6000 \mathrm{~m}$ and by case 1 at $7000 \mathrm{~m}$ with somewhat lower frequencies for the other cases. The 24 May was the day where the nucleation mode particles were observed at $7000 \mathrm{~m}$ during the ASTAR 2004 campaign and as described all cases were present on that day but with the highest occurrence of case 1 . Considering the trajectories that were started near the location where the flights were performed we found that the 22 May $\left(11.0^{\circ} \mathrm{E} / 78.9^{\circ} \mathrm{N}\right)$ as well as the 24 May $\left(22.5^{\circ} \mathrm{E} / 78.2^{\circ} \mathrm{N}\right)$ could be accounted to case 3 while the 26 May $\left(10.0^{\circ} \mathrm{E} / 78.5^{\circ} \mathrm{N}\right)$ could be accounted to case 2.

\subsubsection{Comparison with measurements}

The results of the model simulation are compared with the measurements to suggest which $\mathrm{H}_{2} \mathrm{SO}_{4}$ mixing ratio might have prevailed in the atmosphere. For comparing the simulation results with the measurements the sulfuric acid 


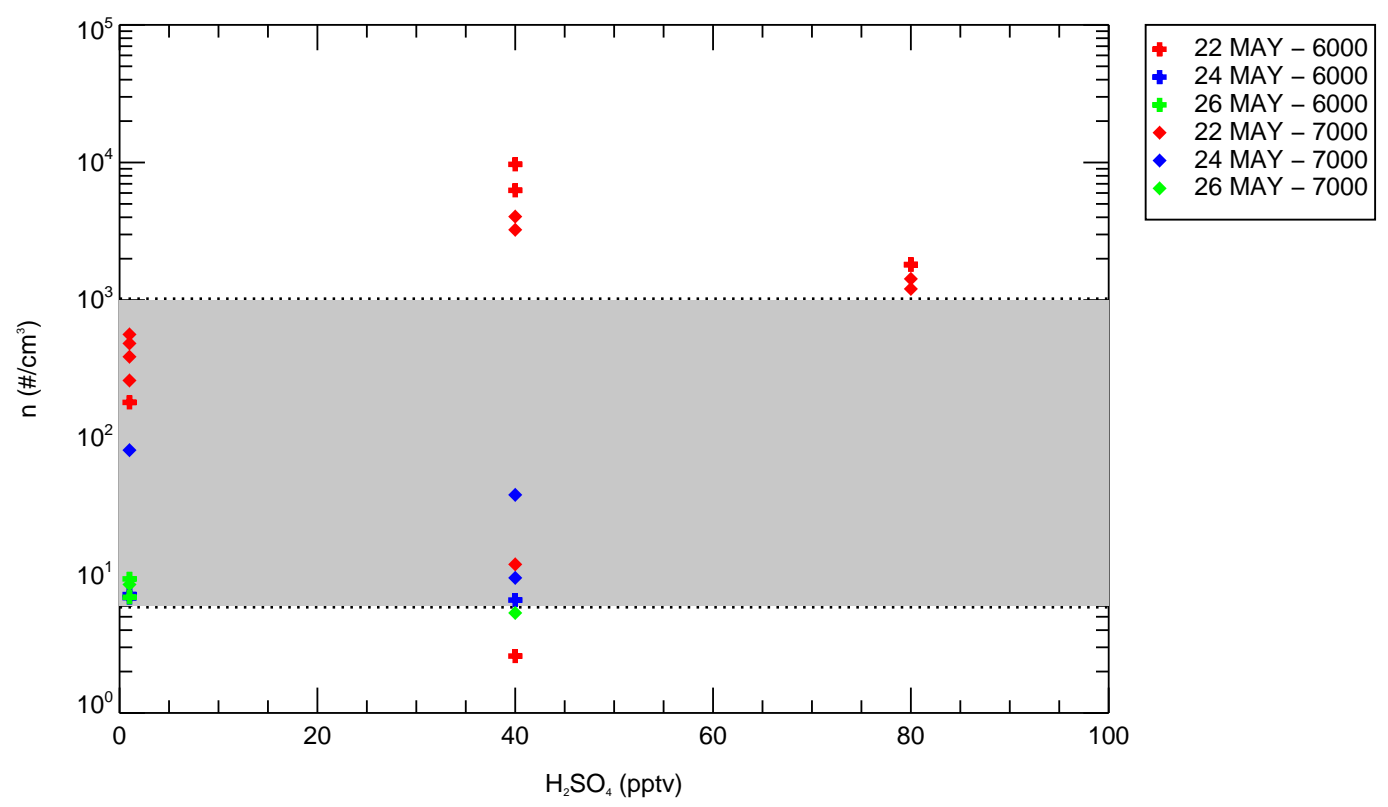

Fig. 9. Sulfuric acid mixing ratio versus the number density of nucleation mode particles encountered at the end of the simulation, thus at the time when the measurement was performed. The gray shaded area marks the number density of the nucleation mode particles (4-13 nm) measured on 24 May during ASTAR 2004. Shown are the number densities for all trajectories started on 22, 24 and 26 May at 6000 and $7000 \mathrm{~m}$.

Table 2. Occurrence of case 1 to case 3 on the 22,24 and 26 May 2004 for the two altitudes (6000 and $7000 \mathrm{~m})$ considered.

\begin{tabular}{lrcccccc}
\hline & Total & $\begin{array}{c}22 \mathrm{May} \\
6000 \mathrm{~m}\end{array}$ & $\begin{array}{c}22 \mathrm{May} \\
7000 \mathrm{~m}\end{array}$ & $\begin{array}{c}24 \text { May } \\
6000 \mathrm{~m}\end{array}$ & $\begin{array}{c}24 \text { May } \\
7000 \mathrm{~m}\end{array}$ & $\begin{array}{c}26 \text { May } \\
6000 \mathrm{~m}\end{array}$ & $\begin{array}{c}26 \mathrm{May} \\
7000 \mathrm{~m}\end{array}$ \\
\hline Case 1 & 19 & 1 & 3 & 2 & 3 & 6 & 4 \\
Case 2 & 7 & 2 & - & 3 & 1 & - & 1 \\
Case 3 & 10 & 3 & 3 & 1 & 2 & - & 1 \\
\hline
\end{tabular}

mixing ratio is plotted versus the number density. Here, the number density at the end of the simulation (which agrees with the time when the flight was performed) for particles with diameters in the nucleation mode particle size range is considered. The gray shaded area in the figure marks the number density of the nucleation mode particles measured during the ASTAR campaign on 24 May 2004. It should be noted here, that there is possible underestimation of $10-35 \%$ due to wall losses in the measured number densities of nucleation mode particles (see Sect. 2.1). In Fig. 9 the results of all trajectories are shown. The 24 May trajectory $(7000 \mathrm{~m})$ as well as some trajectories of the other days (22 May and 26 May) and other starting points in the grid around the measurements lie also within the gray shaded area and thus in the range of nucleation mode particles measured on 24 May. Thereby, $\mathrm{H}_{2} \mathrm{SO}_{4}$ mixing ratios of 1 to $40 \mathrm{pptv}$ seem to be sufficient. $\mathrm{A}_{2} \mathrm{SO}_{4}$ mixing ratio of 80 pptv seems to be too high for all trajectories since no data points are found in the gray shaded area. This is in agreement with measurements of gaseous $\mathrm{H}_{2} \mathrm{SO}_{4}$ which even in polluted areas showed mixing ratios lower than 80 pptv (Bardouki et al., 2003; Berresheim et al., 2002).

A better comparison with the measurements can be derived when only the trajectories that were started near the location where the flights were performed are considered (Fig. 10). The number density found at the end of the simulation for the trajectory started on 24 May (the day where nucleation mode particles were observed) at $7000 \mathrm{~m}$ lies within the range of the measured number densities if the trajectory is initialized with a sulfuric acid mixing ratio of $\mu_{\mathrm{H}_{2} \mathrm{SO}_{4}}=40 \mathrm{pptv}$ (blue diamonds). However, a few hundred particles per $\mathrm{cm}^{3}$ instead of a few tenths were measured during the flight and thus most likely the mixing ratio on that day was somewhat higher than $40 \mathrm{pptv}$. The trajectory started on 22 May at $7000 \mathrm{~m}$ at the location where the flight was performed (initialized with 1 and $40 \mathrm{pptv}$ ) lies also still within the area of number densities measured (red diamonds). However, on this day no nucleation mode particles were measured (thus no data points should be found in the gray shaded area). This indicates that the sulfuric acid mixing ratio must also have been somewhat higher than $40 \mathrm{pptv}$. None of the simulations for the 26 May are present in Fig. 10 since at the end of all simulations number densities for nucleation mode particles were quite low. For 1 pptv the nucleation burst along the trajectory was not strong enough to result in particles in the measured range of nucleation mode particles and for 40 


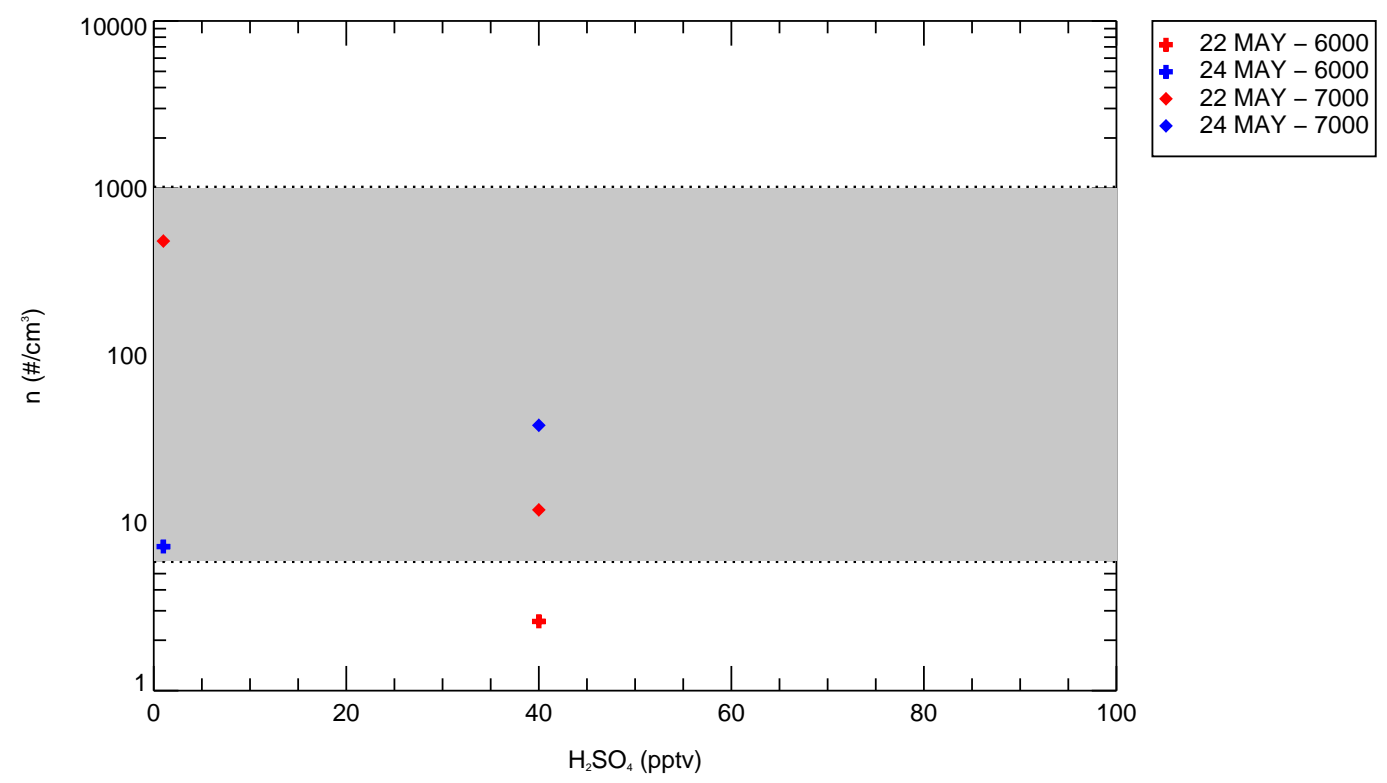

Fig. 10. Sulfuric acid mixing ratio versus the number density encountered at the end of simulation, thus at the time when the measurement was performed. The gray shaded area marks the number density of the nucleation mode particles (4-13 nm) measured on 24 May during ASTAR 2004. Shown are only the number densitities for the trajectories which were started on 22, 24 and 26 May at 6000 and $7000 \mathrm{~m}$ near the location were the flight was performed.

and $80 \mathrm{pptv}$ the nucleation burst was too strong so that the particles had already coagulated to larger sizes (not shown). Since on that day no nucleation mode particles were measured we can conclude that the $\mathrm{H}_{2} \mathrm{SO}_{4}$ mixing ratio on that day must have been definitely lower than $40 \mathrm{pptv}$. A sulfuric acid mixing ratio as low as 1 pptv would be possible since this simulation was in agreement with the measurements.

\subsubsection{What caused the nucleation event on 24 May?}

To investigate why nucleation mode particles were measured on 24 May, but not on 22 May or 26 May, we took a closer look to the parameters we used for the initialization of the box model (see Sect. 4.1) and the parameters we derived from the trajectories and the box model simulations (Table 3). The box model simulations themself show that a nucleation burst was simulated along all trajectories, however, in the majority of the simulations the nucleation rate was either too low or too high so that no nucleation mode particles were left at the end of the simulation. Thus, the question we try to answer here is why were particles in the nucleation mode size range left on 24 May but not on the other days.

The particle size distributions derived from the DMPS were quite similar for all days, thus the particle formation was not initiated by a low number density of preexisting aerosols. Further, the paths of the air mass trajectories (Fig. 3) show that the formation of new particles on 24 May can also not be simply explained by a difference in air mass origin since the trajectories on 24 May (nucleation) and 26 May (non-nucleation) have the same origin. Further, simulations (20-d backwards) that were performed with the FLEXPART model (Stohl et al., 2005) for this campaign show that the $\mathrm{SO}_{2}$ source contribution on all three days was low though the highest contribution of $\mathrm{SO}_{2}$ was found on 24 May. The parameters listed in Table 3 show that the 22 May was a day with a less stable atmosphere (lowest values of $\gamma_{d}$ and highest vertical velocities) and the lowest number densities of new particles were formed on that day. The 24 May was also a less stable day but somewhat more stable than the 22 May. The vertical velocities and the number of particles formed are somewhat lower than on 22 May. The 26 May in contrast was a day with a quite stable stratification. The vertical velocities on that day were quite low but for $\mathrm{H}_{2} \mathrm{SO}_{4}$ mixing ratio of 40 and 80 pptv a higher amount of particles were formed than on the other days.

Considering the temperature (not shown) and pressure (Fig. 11) history along the back trajectories we find that all trajectories show an uplifting of the air mass and according to that a decrease in temperature. However, the strength of this uplifting/cooling events are different on each day (which is in agreement with the parameters listed in Table 3 and discussed in the previous paragraph). The uplifting and cooling was strongest on 22 May. The air mass was lifted from 600 to $350 \mathrm{hPa}$ within $20 \mathrm{~h}$ resulting in a temperature decrease of $30 \mathrm{~K}$ from $255 \mathrm{~K}$ to $225 \mathrm{~K}$ and thus can be considered as a fast updraft. Besides the fact that FLEXPART shows a higher 

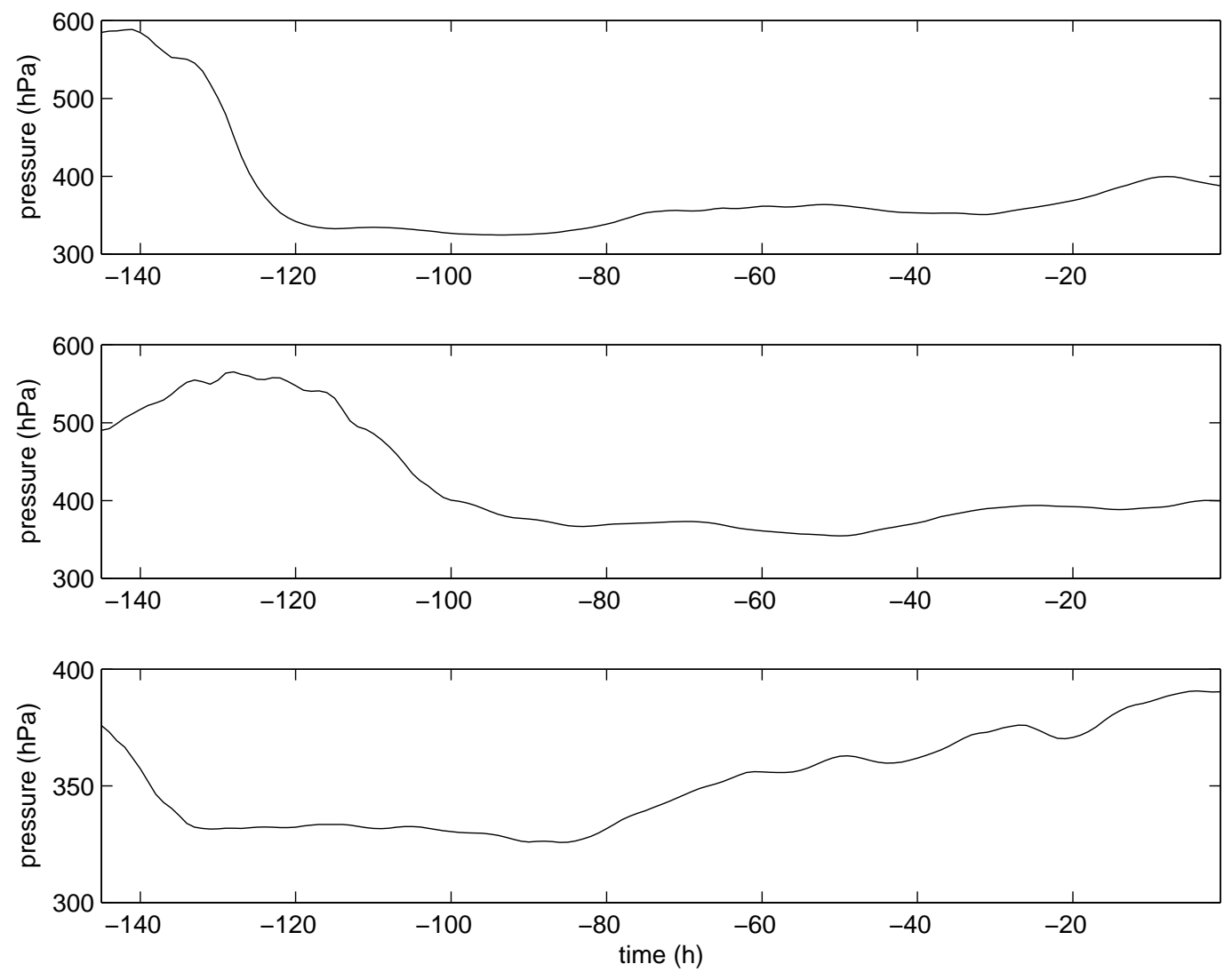

Fig. 11. Pressure along the back trajectories calculated with TRAJKS based on ECWMF analyses (the same trajectories as in Fig. 3). Top: 22 May, middle: 24 May and bottom: 26 May. The time $t=0$ coincides with the measurements and is the starting point of the backward trajectory calculation.

$\mathrm{SO}_{2}$ contribution on 24 May the nucleation was caused by a slow updraft. The air mass was lifted from 550 to $400 \mathrm{hPa}$ in $30 \mathrm{~h}$ which results in a temperature decrease of $25 \mathrm{~K}$ from 255 to $230 \mathrm{~K}$ during that time period. On 26 May which was most stable stratified the air mass was only lifted from 380 to $340 \mathrm{hPa}$ in $10 \mathrm{~h}$ with a temperature decrease of $12 \mathrm{~K}$ from 234 to $226 \mathrm{~K}$. Thus, while on 22 May and 24 May the simulated nucleation event was caused by vertical motion (case 3 ) the nucleation event on 26 May was induced by a combination between vertical motion and other factors like an already sufficient low temperature and a sufficient high $\mathrm{H}_{2} \mathrm{SO}_{4}$ mixing ratio (case 2). Another difference between the trajectories is that the updraft occurred earliest on 26 May (at the begin of the simulation), but somewhat later on 22 May (at $t \approx-140 \mathrm{~h}$ ) and latest on 24 May (at $t \approx-120 \mathrm{~h}$ ).

Thus, we can conclude that the reason why nucleation mode particles were observed on 24 May, but not on 22 May and 26 May was the conditions under which this nucleation event occurred. The nucleation event on 24 May was caused by a slow updraft that lifted and cooled the air mass and resulted in moderate number of newly formed particles. Due to the fact that the nucleation event occurred later on that day than on the other days (thus closer to time of the measurements) not all newly formed particles were removed due to coagulation until the measurements were performed. Our results are in agreement with Benson et al. (2008) who also found differences in the strength of new particles formed due to slow and fast updrafts. However, Benson et al. (2008) performed case studies based on aerosol size distributions measured at latitudes between $18^{\circ} \mathrm{N}-52^{\circ}$ while we use measurements made at $78^{\circ} \mathrm{N}$. Thus, our results indicate this that the influence of slow and fast updrafts is also evident in the polar regions.

\section{Conclusions}

The ASTAR 2004 campaign was performed to investigate aerosol properties in the transition period from Arctic haze to background conditions. Measurements were performed during 19 flights in the time period from 10 May to 7 June 2004. Nucleation mode particles were observed quite frequently in the lower troposphere. However, nucleation mode particles were only observed once in the upper free troposphere (on 
Table 3. Parameters encountered along the trajectories started at the altitude and location where the flights were performed ( 22 May, 24 May and 26 May, respectively). Altitude, time when nucleation occurred, sulfuric acid and water mixing ratio used for initialization of the box model, dry and wet stability, vertical velocity, cooling rate, temperature and number density at the time when nucleation occurred and number density of nucleation mode particles at the end of the simulation are given.

\begin{tabular}{lccccccccccc}
\hline Date & $\begin{array}{c}\mathrm{Altitude} \\
(\mathrm{m})\end{array}$ & $\begin{array}{c}t \\
(\mathrm{~h})\end{array}$ & $\begin{array}{c}\mathrm{H}_{2} \mathrm{O} \\
(\mathrm{ppmv})\end{array}$ & $\begin{array}{c}\mathrm{H}_{2} \mathrm{SO}_{4} \\
(\mathrm{pptv})\end{array}$ & $\begin{array}{c}\gamma_{d} \\
(\mu \mathrm{K} / \mathrm{Pa})\end{array}$ & $\begin{array}{c}\gamma_{w} \\
(\mu \mathrm{K} / \mathrm{Pa})\end{array}$ & $\begin{array}{c}w \\
(\mathrm{~cm} / \mathrm{s})\end{array}$ & $\begin{array}{c}d T / d t \\
(\mathrm{~K} / \mathrm{h})\end{array}$ & $\begin{array}{c}T \\
(\mathrm{~K})\end{array}$ & $\begin{array}{c}n \\
\left(\mathrm{~cm}^{-3}\right)\end{array}$ & $\begin{array}{c}n_{\text {nucl }} \\
\left(\mathrm{cm}^{-3}\right)\end{array}$ \\
\hline 22 May & 7000 & 22 & 178 & 11 & 1493 & 1444 & 5 & -1.8 & 228 & $2 \times 10^{7}$ & 488 \\
22 May & 7000 & 17 & 178 & 40 & 1286 & 1198 & 9 & -3.5 & 241 & $6 \times 10^{6}$ & 112 \\
22 May & 7000 & 16 & 178 & 80 & 1235 & 1104 & 8 & -3.5 & 244 & $7 \times 10^{6}$ & 20 \\
\hline 24 May & 7000 & 47 & 116 & 11 & 1698 & 1633 & 1 & -0.4 & 235 & $2 \times 10^{5}$ & 20 \\
24 May & 7000 & 37 & 116 & 40 & 1674 & 1602 & 4 & -1.5 & 245 & $2 \times 10^{6}$ & 138 \\
24 May & 7000 & 12 & 116 & 80 & 1642 & 1569 & -3 & 01.0 & 250 & $1 \times 10^{7}$ & 20 \\
\hline 26 May & 7000 & 14 & 198 & 11 & 1696 & 1611 & 1 & -0.5 & 232 & $4 \times 10^{5}$ & 20 \\
26 May & 7000 & 12 & 198 & 40 & 1779 & 1660 & 1 & -0.5 & 233 & $4 \times 10^{8}$ & 20 \\
26 May & 7000 & 12 & 198 & 80 & 1779 & 1660 & 1 & -0.5 & 233 & $4 \times 10^{8}$ & 20 \\
\hline
\end{tabular}

24 May at $7000 \mathrm{~m})$. The aim of this study was to investigate the influence of vertical motion on the particle formation. Therefore, microphysical box model simulations were performed for the ASTAR 2004 campaign on three days (nucleation/non-nucleation) along trajectories that were calculated based on ECMWF meteorological analyses. Due to the lack of measurements of $\mathrm{H}_{2} \mathrm{SO}_{4}$ the simulations were performed using three different mixing ratios (1, 40 and 80 pptv). The simulation results could be divided into three cases. (1) Nucleation occurs immediately at the begin of the simulation as temperatures were low enough to initiate particle nucleation, (2) as case 1 , but for $\mu_{\mathrm{H}_{2} \mathrm{SO}_{4}}=1$ pptv nucleation occurred at a later point in the simulation when more favorable conditions for particle nucleation were encountered, (3) nucleation occurred at three different time steps during the simulation independent from which $\mathrm{H}_{2} \mathrm{SO}_{4}$ mixing ratio was used. Several observations in the free troposphere (midlatitude) showed that new particle formation can occur in connection with convection and thus vertical motion (e.g. de Reus et al., 1999; Twohy et al., 2002; Benson et al., 2008). Parameters like dry and wet stability as well as vertical velocity along the trajectories were used as a proxy if vertical motion were involved in the particle formation process. Thereby, we found that for case 1 the driving force was the temperature while for case 2 and 3 vertical motions were involved in the particle formation. Considering the trajectories that were started near the location where the flights were performed we found that the 22 May as well as the 24 May could be accounted to case 3 while the 26 May could be accounted to case 2 . We compared the results of the model simulations with the measurements to get an idea which $\mathrm{H}_{2} \mathrm{SO}_{4}$ mixing ratio might has prevailed in the atmosphere. Thereby, we found that the $\mathrm{H}_{2} \mathrm{SO}_{4}$ mixing ratio prevailing in the atmosphere was most likely somewhat higher than 40 pptv on 22 and 24 May, but probably much lower than 40 pptv on 26 May. A nucleation burst was simulated along all trajectories, however, in the majority of the simulations the nucleation rate was either too low or too high so that no nucleation mode particles were left at the end of the simulation. The reason why nucleation mode particles were observed on 24 May but not on 22 or 26 May is due to the conditions under which nucleation occurred on 24 May. The nucleation event on 24 May was caused by a slow updraft that lifted and cooled the air mass and resulted in a moderate number of newly formed particles. Due to the fact that the nucleation event occurred later on that day than on the other days (thus closer to the time of the measurements) not all newly formed particles were removed due to coagulation until the measurements were performed. Our results are in agreement with the findings of Benson et al. (2008) who also found different nucleation behaviors due to slow and fast updrafts. Further, our results emphasize in consistence with previous case studies (de Reus et al., 1999; Twohy et al., 2002; Benson et al., 2008) the importance of vertical motion on new particle formation. Especially, here for the first time it has been shown that vertical motion also are important in the polar regions.

Acknowledgements. We would like to thank P. Konopka for the diffusive uptake code, B. Kärcher for the nucleation code and P. Deuflhard and U. Nowak for providing the solver for ordinary differential equations. We also would like to thank the ECMWF for providing meteorological analyses, A.-C. Engvall for providing the particle size distributions, R. Treffeisen for providing the radiosonde data, $\mathrm{R}$. Scheele for providing the air parcel trajectories, A. Stohl for providing the FLEXPART simulations, S.-H. Lee and R. Müller for helpful discussions and S. Lossow for helpful 
comments on a previous of the version of the manuscript. Further, we also would like to thank the reviewers for their helpful comments. We are also grateful to the European Commission (EU 6th Framework Programme Marie-Curie Intra-European Fellowships) and the Swedish Research Council for funding F. Khosrawi.

Edited by: M. Wendisch

\section{References}

Bardouki, H., Berresheim, H., Vrekoussis, M., Sciare, J., Kouvarakis, G., Oikonomou, K., Schneider, J., and Mihalopoulos, N.: Gaseous (DMS, MSA, $\mathrm{SO}_{2}, \mathrm{H}_{2} \mathrm{SO}_{4}$ and DMSO) and particulate (sulfate and methanesulfonate) sulfur species over the northeastern coast of Crete, Atmos. Chem. Phys., 3, 1871-1886, 2003,

http://www.atmos-chem-phys.net/3/1871/2003/.

Baumgardner, D., Dye, J. E., Gandrud, B. W., and Knollenberg, R. G.: Interpretation of measurements made by the Forward Scattering Spectrometer Probe (FSSP300) during the airborne Artic stratospheric expedition, J. Geophys. Res., 97, 8035-8046, 1992.

Benson, D. R., Li-Hao Young, , Shan-Hu Lee, , Campos, T. L., Rogers, D. C., and Jensen, J.: The effects of airmass history on new particle formation in the free troposphere: case studies, Atmos. Chem. Phys., 8, 3015-3024, 2008,

http://www.atmos-chem-phys.net/8/3015/2008/.

Benson, D. R., Erupe, M. E. and Lee, S.-H.: Laboratorymeasured $\mathrm{H}_{2} \mathrm{SO}_{4}-\mathrm{H}_{2} \mathrm{O}-\mathrm{NH}_{3}$ ternary homogeneous nucleation rates: Initial observations, Geophys. Res. Lett., 36, L15818, doi:10.1029/2009GL038728, 2009.

Berresheim, H., Elste, T., Tremmel, H. G., Allen, A. G., Hansson, H.-C., Rosman, K., Del Maso, M., Mäkela, J. M., Kulmala, M., and O'Dowd, C. D.: Gas-aerosol relationship of $\mathrm{H}_{2} \mathrm{SO}_{4}, \mathrm{MSA}$, and $\mathrm{OH}$ : Observations in the coastal marine boundary layer at Mace Head, Ireland, J. Geophys. Res., 107, 8100, doi:10.1029/2000JD000229, 2002.

Blum, U., Khosrawi, F., Baumgarten, G., Stebel, K., Müller, R., and Fricke, K. H.: Simultaneous lidar observations of a polar stratospheric cloud on the east and west sides of the Scandinavian mountains and microphysical box model simulations, Ann. Geophys., 24, 3267-3277, 2006, http://www.ann-geophys.net/24/3267/2006/.

Bodhaine, B. A.: Barrow surface aerosol - 1976-1986, Atmos. Environ., 23, 2357-2369, 1989.

Brock, C. A., Radke, L. F., Lyons, J. H., and Hobbs, P. V.: Arctic hazes in summer over greenland and the North American Arctic: I: Incidence and origin, J. Atmos. Chem., 9, 129-148, 1989.

Brock, C. A., Hamill, P., Wilson, J. C., Jonsson, H. H., and Chan, K. R.: Particle formation in the upper tropical troposphere: A source of nuclei for the stratospheric aerosol, Science, 270, 1650-1653, 1995.

Coffmann, D. J. and Hegg, D. A.: A prelimenary study of the effect of ammonia on particle nucleation in the marine boundary layer, J. Geophys. Res., 100, 7147-7160, 1995.

Curtius, J., Sierau, B., Arnold, F., de Reus, M., Ström, J., Scheeren, H. A., and Lelieveld, J.: Measurement of aerosol sulfuric acid 2. Pronounced layering in the free troposphere during the second
Aerosol Characterization Experiment (ACE 2), J. Geophys. Res., 106, 31975-31990, 2001.

Curtius, J., Lovejoy, E. R. and Froyd, K. D.: Atmospheric ioninduced aerosol nucleation, Space Sci. Rev., 125, 159-167, 2006.

de Reus, M., Ström, J., Kulmala, M., Pirjola, L., Lelieveld, J., Schiller, C., and Zöger, M.: Airborne aerosol measurements in the tropopause region and the dependence of new particle formation on preexisting number concentrations, J. Geophys. Res., 103, 31155-31263, 1998.

de Reus, M., Ström, J., Hoor, P., Lelieveld, J., and Schiller, C.: Particle production in the lowermost stratosphere by convective lifting of the tropopause, J. Geophys. Res., 104, 23935-23940, 1999.

Deuflhard, P.: Recent progress in extrapolation methods for ordinary differential equations, Journal of the Society for Industrial and Applied Mathematics, 27, 505-535, 1985.

Eisele, F. L. and Tanner, D. J.: Measurement of the gas phase concentration of $\mathrm{H}_{2} \mathrm{SO}_{4}$ and methane sulfonic acid and estimates of $\mathrm{H}_{2} \mathrm{SO}_{4}$ production and loss in the atmosphere, J. Geophys. Res., 98, 9001-9010, 1993.

Engvall, A. C., Krejci, R., Ström, J., Minikin, A., Treffeisen, R., Stohl, A., and Herber, A.: In-situ airborne observations of the microphysical properties of Arctic tropospheric aerosol during late spring and summer, Tellus B, 60, 392-404, 2008.

Fuchs, N. A.: Mechanics of Aerosols, Pergamon, New York, 1977.

Gayet, J.-F., Stachlewska, I. S., Jourdan, O., Shcherbakov, V., Schwarzenboeck, A., and Neuber, R.: Microphysical and optical properties of precipitating drizzle and ice particles obtained from alternated lidar and in situ measurements, Ann. Geophys., 25, 1487-1497, 2007, http://www.ann-geophys.net/25/1487/2007/.

Hamill, P., Jensen, E. J., Russell, P. B., and Bauman, J. J.: The life cycle of stratospheric aerosol particles, B. Am. Meteor. Soc., 78(7), 1395-1410, 1997.

Hegg, D. A. and Baker, M. B.: Nucleation in the atmosphere, Rep. Prog. Phys., 72, 1-21, 2009.

Hermann, M., Heintzenberg, J., Wiedensohler, A., Zahn, A., Heinrich, G., and Breninkmeijer, C. A. M.: Meriodional distribution of aerosol particle number concentration in the upper troposphere and lower stratosphere obtained by Civil Aircraft for Regular Investigation of the Atmosphere Based on an Instrument Container (CARIBIC) flights, J. Geophys. Res., 108, 4114, doi:10.1029/2001JD001077, 2003.

IPCC: Intergovernmental Panel on Climate Change: Climate Change 2007, Cambridge University Press, Cambridge, UK, 2007.

Jaecker-Voirol, A., Mirabel, P., and Reiss, H.: Hydrates in supersaturated binary sulfuric acid-water vapour: A reexamination, J. Chem. Phys., 87, 4849-4852, 1987.

Kärcher, B.: Physiochemistry of aircraft-generated liquid aerorsols, soot and ice particles, J. Geophys. Res., 103, 17111-17128, 1998.

Kerminen, V.-M. and Kulmala, M.: Analytical formulae connecting the "real" and the "apparent" nucleation rate and the nuclei number concentration for atmospheric nucleation events, J. Aerosol Sci., 22, 609-622, 2002.

Khosrawi, F. and Konopka, P.: Enhancement of nucleation and condensation rates due to mixing processes in the tropopause region, Atmos. Environ., 37, 903-910, 2003. 
Khosrawi, F., Müller, R., Beuermann, J., Konopka, P., and Schiller, C.: Dehydration in the northern hemisphere midlatitude tropopause region observed during stream 1998, Tellus, 58B, 206-217, 2006.

Korhonen, P., Kulmala, M., Laaksonen, A., Viisanen, Y., McGraw, R., and Seinfeld, J. H.: Ternary nucleation of $\mathrm{H}_{2} \mathrm{SO}_{4}$, $\mathrm{NH}_{3}$ and $\mathrm{H}_{2} \mathrm{O}$ in the atmosphere, J. Geophys. Res., 104, 2634926353, 1999.

Kulmala, M., Vehkamäki, H., Petälä, T., Dal Maso, M., Lauri, A., Kerminen, V.-M., Birmili, W., and McMurry, P. H.: Formation and growth rates of ultrafine atmospheric particles: a review of observations, J. Aerosol Sci., 35, 143-176, 2004.

Kulmala, M., Reisell, A., Sipilä, M., Bonn, B., Ruuskanen, T. M., Lehtinen, K. E., Kerminen, V.-M., and Ström, J.: Deep convective clouds as aerosol production engines: Role of insoluble organics, J. Geophys. Res., 111, D17202, doi:10.1029/2005JD006963, 2006.

Laaksonen, A. and Kulmala, M.: Homogeneous heteromolecular nucleation of acid and water vapours in stratospheric conditions: a theoretical study on the effect of hydrate interaction, J. Aerosol Sci., 22, 779-787, 1991.

Laaksonen, A., Kulmala, M., Berndt, T., Stratmann, F., Mikkonen, S., Ruuskanen, A., Lehtinen, K. E. J., Dal Maso, M., Aalto, P., Petäjä, T., Riipinen, I., Sihto, S.-L., Janson, R., Arnold, F., Hanke, M., Ücker, J., Umann, B., Sellegri, K., O’Dowd, C. D., and Viisanen, Y.: $\mathrm{SO}_{2}$ oxidation products other than $\mathrm{H}_{2} \mathrm{SO}_{4}$ as a trigger of new particle formation, Part 2: Comparison of ambient and laboratory measurements, and atmospheric implications, Atmos. Chem. Phys., 8, 7255-7264, 2008,

http://www.atmos-chem-phys.net/8/7255/2008/.

Lee, S.-H., Reeves, J. M., Wilson, J. C., Hunton, D. E., Viggiano, A. A., Miller, T. M., Ballenthin, J. O., and Lait, L. R.: Particle formation by ion nucleation in the upper troposphere and lower stratosphere, Science, 301, 1886-1889, 2003.

Lovejoy, E., Curtius, J., and Froyd, K. D.: Atmospheric ion-induced nucleation of sulfuric acid and water, J. Geophys. Res., 109, D08204, doi:10.1029/2003JD004460, 2004.

Luo, B., Carslaw, K. S., Peter, T., and Clegg, S. L.: Vapour pressures of $\mathrm{H}_{2} \mathrm{SO}_{4} / \mathrm{HNO}_{3} / \mathrm{HCl} / \mathrm{HBr} / \mathrm{H}_{2} \mathrm{O}$ solutions to low stratospheric temperatures, Geophys. Res. Lett., 22, 247-250, 1995.

Minikin, A., Petzold, A., Ström, J., Krejci, R., Seifert, M., Velthoven, P. V., Schlager, H., and Schumann, U.: Aircraft observations of the upper tropospheric fine particle aerosol in the northern and southern hemispheres at midlatitudes, Geophys. Res. Lett., 30, 1503, doi:10.1029/2002GL016458, 2003.

Napari, I., Hoppel, M., Vehkamäki, H., and Kulmala, M.: An improved model for ternary nucleation of sulfuric-acid-ammonia water, J. Chem. Phys., 116, 4221-4227, 2002.

Pruppacher, H. and Klett, J. D.: Microphysics of Clouds and Precipitation, D. Reidel, Norwell, Mass., 1978.
Scheele, M. P., Sigmund, P. C., and van Velthoven, P. F. J.: Sensitivity of trajectories to data resolution and its dependence on the starting point: in or outside a tropopause fold, Meteorol. Appl., 3, 267-273, 1996.

Stohl, A., Haimberger, L., Scheele, M. P., and Wernli, H.: An intercomparison of results from three trajectory models, Meteorol. Appl., 8, 127-135, 2001.

Stohl, A., Forster, C., Frank, A., Seibert, P., and Wotawa, G.: Technical note: The Lagrangian particle dispersion model FLEXPART version 6.2, Atmos. Chem. Phys., 5, 2461-2474, 2005, http://www.atmos-chem-phys.net/5/2461/2005/.

Ström, J., Umegard, J., Torseth, K., Tunved, P., Hansson, H. C., Holmen, K., Wismann, V., Herber, A., and König-Langlo, G.: One year of particle size distribution and aerosol chemical composition measurements at the Zeppelin station, Svalbard, March 2000-March 2001, Phys. Chem. Earth, 28, 1181-1190, 2003.

Twohy, C. H., Clement, C. F., Gandrud, B. W., Weinheimer, A. J., Campos, T. L., Baumgardner, D., Brune, W. H., Faloona, I., Sachse, G. W., Vay, S. A., and Tan, D.: Deep convection as a source of new particles in the midlatitude upper troposphere, J. Geophys. Res., 107, 4560, doi:10.1029/2001JD000323, 2002.

Weber, R. J., Murry, P. H., Mauldin III, R. L., Tanner, D. J., Eisele, F. L., Clarke, A. D., and Kapustin, V. N.: New particle formation in the remote troposphere: A comparison of observations at various sites, Geophys. Res. Lett., 26, 307-310, 1999.

Weber, R. J., Orsinin, D., Wang, B., Scheuer, E., Talbot, R. W., Dibb, J. E., Seid, G. K., DeBell, L., Maulrin, R. L., Kosciuch, E., Cantrell, C., and Eisele, F.: Investigations into free tropospheric new particle formation in the central Canadian Arctic during the winter/spring transition as part of TOPSE, J. Geophys. Res., 108, 8357, doi:10.1029/2002JD002239, 2003.

Young, L.-H., Benson, D. R., Montanaro, W. M., Lee, S.-H., Pan, L. L., Rogers, D. C., Jensen, J., Stith, J. L., Davis, C. A., Campos, T. L., Bowman, K. P., Cooper, W. A., and Lait, L. R.: Enhanced new particle formation observed in the Northern Hemisphere midlatitude tropopause region, J. Geophys. Res., 112, D10218, doi:10.1029/2006JD008109, 2007.

Yu, F.: Effect of ammonia on new particle formation: A kinetic $\mathrm{H}_{2} \mathrm{SO}_{4}-\mathrm{H}_{2} \mathrm{O}-\mathrm{NH}_{3}$ nucleation model constrained by laboratory measurements, J. Geophys. Res., 111, D10204, doi:10.1029/2005JD005968, 2006.

Yu, F. and Turco, R. P.: Ultrafine aerosol formation via ionmediated nucleation, Geophys. Res. Lett., 27, 883-886, 2000.

Zahn, A., Brenninkmeijer, C. A. M., Meiss, M., Scharffe, D. H., Crutzen, P. J., Hermann, M., Heintzenberger, J., Wiedersohler, A., Güsten, A., Heinrich, G., Fischer, H., Cuijpers, J. W. M., and van Velthoven, P. F. J.: Identification of extratopical twoway troposphere-stratosphere mixing based on CARIBIC measurements of $\mathrm{O}_{3}, \mathrm{CO}$, and ultrafine particles, J. Geophys. Res., $105,1527-1535,2000$. 